Review

\title{
Dirofilaria spp. and Angiostrongylus vasorum: Current Risk of Spreading in Central and Northern Europe
}

\author{
Hans-Peter Fuehrer $1, *,+\left(\mathbb{D}\right.$, Simone Morelli $2,+\left(\mathbb{C}\right.$, Maria Sophia Unterköfler ${ }^{1,+}+\mathbb{C}$, Anna Bajer $^{3}(\mathbb{D}$, \\ Karin Bakran-Lebl ${ }^{1}{ }^{\oplus}$, Dorota Dwużnik-Szarek ${ }^{3}$, Róbert Farkas ${ }^{4}$, Giulio Grandi ${ }^{5,6}$, Mike Heddergott ${ }^{7}\left({ }^{10}\right.$, \\ Pikka Jokelainen $\left.{ }^{8}{ }^{(}\right)$, Tanja Knific ${ }^{9}{ }^{\circledR}$, Michael Leschnik ${ }^{10}$, Martina Miterpáková ${ }^{11}{ }^{\oplus}$, David Modrý ${ }^{12,13,14}$, \\ Heidi Huus Petersen ${ }^{15}{ }^{\oplus}$, Karl Skírnisson ${ }^{16}$, Aleksandra Vergles Rataj ${ }^{17}$, Manuela Schnyder ${ }^{18}(\mathbb{D}$ \\ and Christina Strube ${ }^{19}$
}

\section{check for} updates

Citation: Fuehrer, H.-P.; Morelli, S.; Unterköfler, M.S.; Bajer, A.;

Bakran-Lebl, K.; Dwużnik-Szarek, D.;

Farkas, R.; Grandi, G.;

Heddergott, M.; Jokelainen, P.; et al Dirofilaria spp. and Angiostrongylus vasorum: Current Risk of Spreading in Central and Northern Europe.

Pathogens 2021, 10, 1268. https://

doi.org/10.3390/pathogens10101268

Academic Editor: Fabrizio Bruschi

Received: 6 September 2021

Accepted: 24 September 2021

Published: 1 October 2021

Publisher's Note: MDPI stays neutral with regard to jurisdictional claims in published maps and institutional affiliations.

Copyright: (C) 2021 by the authors Licensee MDPI, Basel, Switzerland. This article is an open access article distributed under the terms and conditions of the Creative Commons Attribution (CC BY) license (https:/ / creativecommons.org/licenses/by/ $4.0 /)$.
1 Department of Pathobiology, Institute of Parasitology, University of Veterinary Medicine Vienna, Veterinärplatz 1, 1210 Vienna, Austria; Maria.Unterkoefler@vetmeduni.ac.at (M.S.U.); karin.bakran-lebl@vetmeduni.ac.at (K.B.-L.)

2 Faculty of Veterinary Medicine, University of Teramo, 64100 Teramo, Italy; smorelli@unite.it

3 Department of Eco-Epidemiology of Parasitic Diseases, Institute of Developmental Biology and Biomedical Sciences, Faculty of Biology, University of Warsaw, Miecznikowa 1, 02-096 Warsaw, Poland; anabena@biol.uw.edu.pl (A.B.); dorota.dwuznik@biol.uw.edu.pl (D.D.-S.)

4 Department of Parasitology and Zoology, University of Veterinary Medicine, 1078 Budapest, Hungary Farkas.Robert@univet.hu

5 Section for Parasitology, Department of Biomedical Sciences and Veterinary Public Health, Swedish University of Agricultural Sciences (SLU), 75007 Uppsala, Sweden; giulio.grandi@slu.se

6 Department of Microbiology, National Veterinary Institute (SVA), 75651 Uppsala, Sweden

7 Department of Zoology, Musée National d'Historire Naturelle, 25, Rue Münster, 2160 Luxembourg, Luxembourg; mike-heddergott@web.de

8 Department of Bacteria, Parasites and Fungi, Infectious Disease Preparedness, Statens Serum Institut, Artillerivej 5, DK-2300 Copenhagen S, Denmark; PIJO@ssi.dk

9 Institute of Food Safety, Feed and Environment, Veterinary Faculty, University of Ljubljana, Gerbičeva 60, 1000 Ljubljana, Slovenia; tanja.knific@vf.uni-lj.si

10 Clinical Unit of Internal Medicine Small Animals, Department/Universitätsklinik für Kleintiere und Pferde, University of Veterinary Medicine Vienna, Veterinärplatz 1, 1210 Vienna, Austria; Michael.leschnik@vetmeduni.ac.at

11 Institute of Parasitology, Slovak Academy of Sciences, Hlinkova 3, 04001 Košice, Slovakia; miterpak@saske.sk

12 Biology Center, Institute of Parasitology, Czech Academy of Sciences, 37005 Ceske Budejovice, Czech Republic; ModryD@VFU.cz

13 Department of Veterinary Sciences, Faculty of Agrobiology, Food and Natural Resources/CINeZ, Czech University of Life Sciences Prague, 16500 Praha-Suchdol, Czech Republic

14 Department of Botany and Zoology, Faculty of Science, Masaryk University, 61137 Brno, Czech Republic

15 Centre for Diagnostic, Department of Health Technology, Technical University of Denmark, 2800 Kongens Lyngby, Denmark; hhpet@dtu.dk

16 Institute for Experimental Pathology at Keldur, University of Iceland, Keldnavegur 3, 112 Reykjavik, Iceland; karlsk@hi.is

17 Institute of Microbiology and Parasitology, Veterinary Faculty, University of Ljubljana, Gerbičeva 60, 1000 Ljubljana, Slovenia; Aleksandra.VerglesRataj@vf.uni-lj.si

18 Institute of Parasitology, Vetsuisse Faculty, University of Zurich, 8057 Zürich, Switzerland; Manuela.Schnyder@uzh.ch

19 Centre for Infection Medicine, Institute for Parasitology, University of Veterinary Medicine Hannover, 30559 Hannover, Germany; Christina.Strube@tiho-hannover.de

* Correspondence: hans-peter.fuehrer@vetmeduni.ac.at; Tel.: +43 (1) 25077-2205

+ These three authors contributed equally to this work.

Abstract: In the past few decades, the relevance of Dirofilaria immitis and Dirofilaria repens, causing cardiopulmonary and subcutaneous dirofilariosis in dogs and cats, and of Angiostrongylus vasorum, causing canine angiostrongylosis, has steadily increased in Central and Northern Europe. In this review, a summary of published articles and additional reports dealing with imported or autochthonous cases of these parasites is provided for Central (Austria, Czechia, Germany, Hungary, Luxemburg, Poland, Slovakia, Slovenia, and Switzerland) and Northern (Denmark, Finland, Iceland, Norway, and Sweden) Europe. Research efforts focusing on Dirofilaria spp. and A. vasorum have varied by country, 
and cross-border studies are few. The housing conditions of dogs, pet movements, the spread of competent vectors, and climate change are important factors in the spread of these nematodes. Dogs kept outside overnight are a major factor for the establishment of Dirofilaria spp. However, the establishment of invasive, diurnal, synanthropic, competent mosquito vectors such as Aedes albopictus may also influence the establishment of Dirofilaria spp. The drivers of the spread of $A$. vasorum remain not fully understood, but it seems to be influenced by habitats shared with wild canids, dog relocation, and possibly climatic changes; its pattern of spreading appears to be similar in different countries. Both Dirofilaria spp. and A. vasorum merit further monitoring and research focus in Europe.

Keywords: Central Europe; Northern Europe; Dirofilaria immitis; Dirofilaria repens; Angiostrongylus vasorum

\section{Introduction}

In the past few decades, arthropod-borne and gastropod-borne pet diseases have changed their distribution. A series of drivers, including wildlife-habitat reduction, urbanization, climatic changes, increased movements of pets traveling with their owners, and animal rehoming, have favored the geographical spread of specific arthropod-borne and gastropod-borne diseases within endemic areas, and their emergence in previously free areas [1-7]. In Europe, this has led to the modification of the epizootiological picture of diseases with key relevance in veterinary medicine, e.g., of cardiopulmonary and subcutaneous dirofilariosis caused by Dirofilaria immitis and Dirofilaria repens, respectively, and of canine angiostrongylosis due to Angiostrongylus vasorum, which have expanded their geographical distribution [4,8-13].

Canines are the main definitive hosts and primary reservoir of $D$. immitis and D. repens $[9,14,15]$. Nevertheless, these filarioids have moderate host specificity and are able to infect a wide range of vertebrates, also including cats and humans [9,14-19].

Adults of $D$. immitis live in the pulmonary arteries and, occasionally, the right chambers of the hearts of definitive hosts. After mating, females release first-stage larvae (L1), known as microfilariae, into the bloodstream. During the blood meal, microfilariae are picked up by mosquitoes, within which they develop to the third infective larval stages (L3). When feeding on vertebrate hosts, infected mosquitoes transmit L3, which undergo two further larval stages and then reach the adult stage with patency of six months [14,15]. Canine heartworm disease (HWD), caused by D. immitis, is usually a chronic cardiorespiratory disease that can be fatal if not treated [20]. Clinical signs include cough, exercise intolerance, dyspnea, and ascites; in severe cases, pulmonary hypertension, heartworm thromboembolism, and heart failure may occur $[15,20]$. Cats are less suitable hosts than dogs; they usually harbor a low number of adult $D$. immitis, and patent infections are rare [17]. In cats, the arrival and early death of immature adults in the pulmonary arteries causes a marked inflammatory response known as heartworm-associated respiratory disease (HARD), characterized by dyspnea, cough, anorexia, and vomiting [17,21]. Cats that survive the HARD phase can become subclinically infected until the death of adult heartworms, which may result in a sudden fatal outcome [17]. Human infections with D. immitis usually result in pulmonary granulomas known as "coin lesions", and can be asymptomatic or present with cough and nonspecific signs [14,22]. The available literature has no reports of human infections with microfilaremia.

The lifecycle of $D$. repens is very similar to the one of $D$. immitis, with the main difference represented by the final localization of the adult stages in the vertebrate hosts, i.e., the subcutaneous and intramuscular connective tissues [9]. Most canine infections are subclinical; in the case of the appearance of clinical signs, non-painful subcutaneous nodules, pruritus, erythema, alopecia, and papulae can be observed [23-25]. The disease in cats is similar, with pruritus, alopecia, erythema, and papulae as the most frequent clinical manifestations [24]. Dirofilaria repens has higher zoonotic potential if compared 
to D. immitis, and thereby has public-health relevance in Europe [9]. Human infection with $D$. repens can present as subcutaneous nodules, mostly in the facial region, perioral and periorbital tissue, scrotum and testicles in men, and breasts in women; it is rarely microfilaremic $[9,26]$.

Dirofilaria immitis and D. repens are traditionally endemic in Southern and Eastern Europe $[9,10,27]$. Nevertheless, a recent increase in the number of cases was reported in Central and Northern Europe, and adjacent regions for both nematodes [9-13,18]. Global warming is regarded as a key factor involved in the spreading of Dirofilaria spp., as it enhances the development of these filarioids inside mosquitoes [9,28].

Canine angiostrongylosis has been a predominant disease in canine veterinary medicine in the last 10 years. Similar to $D$. immitis, adults of $A$. vasorum inhabit the pulmonary arteries of definitive hosts [8]. After mating, females lay eggs that hatch and release L1, penetrate the alveoli, reach the pharynx, and then are swallowed and excreted with feces into the environment $[8,29,30]$. Thereafter, L1 penetrate or are ingested by a terrestrial gastropod (e.g., snails or slugs), within which they develop to L3. Dogs become infected when ingesting infected molluscs $[29,31]$. The diagnosis of canine angiostrongylosis is challenging for veterinary practitioners. Clinical pictures may be extremely variable, as (i) they range from subclinical to hyperacute, and (ii) infected dogs can display a plethora of different clinical signs that are both cardiorespiratory and nonspecific, gastrointestinal, neurological, and related to coagulation disorders [32-36]. The definitive host spectrum of $A$. vasorum is narrower than that of Dirofilaria spp., as it infects almost exclusively canids, with only few descriptions in other animals [8,37-40]. A single case of a natural non-patent infection was documented in a domestic cat [41], though the importance of feline angiostrongylosis due to A. vasorum or Angiostrongylus chabaudi is considered to be minimal at present, with patent infections reported only in wildcats [42,43]. At present, A. vasorum does not have any relevance to human health.

Several new records in both definitive and intermediate hosts documented a geographical expansion of A. vasorum in previously free areas, including the Iberian Peninsula [44,45] and Eastern [46-50], Central, and Northern Europe [51-54].

The geographical expansion of Dirofilaria spp. and A. vasorum in areas that were previously considered to be non-enzootic requires constant epizootiological surveillance (Figure 1). These changes could partly be attributed to the increased interest of scientists and the pharma industry (funding studies), also strongly contributing to the development of new treatment options. An increase in the awareness of local veterinarians and owners is warranted, as there is a lack of updated data in many countries, and dogs may be at risk of infection with both Dirofilaria spp. and A. vasorum, even in areas where their presence is currently unexpected. The situation is a challenge for the veterinary profession, and regarding the zoonotic Dirofilaria spp., also for medical profession, particularly in areas where the parasites have recently emerged or are not yet established $[55,56]$.

Although the number of studies has increased in the last few years, epizootiological knowledge on Dirofilaria spp. and A. vasorum in Central and Northern Europe is still fragmentary. Therefore, the aim of the present study is to comprehensively review epizootiological data from countries of Central and Northern Europe in order to provide an updated and accurate picture on canine dirofilariosis and angiostrongylosis. 


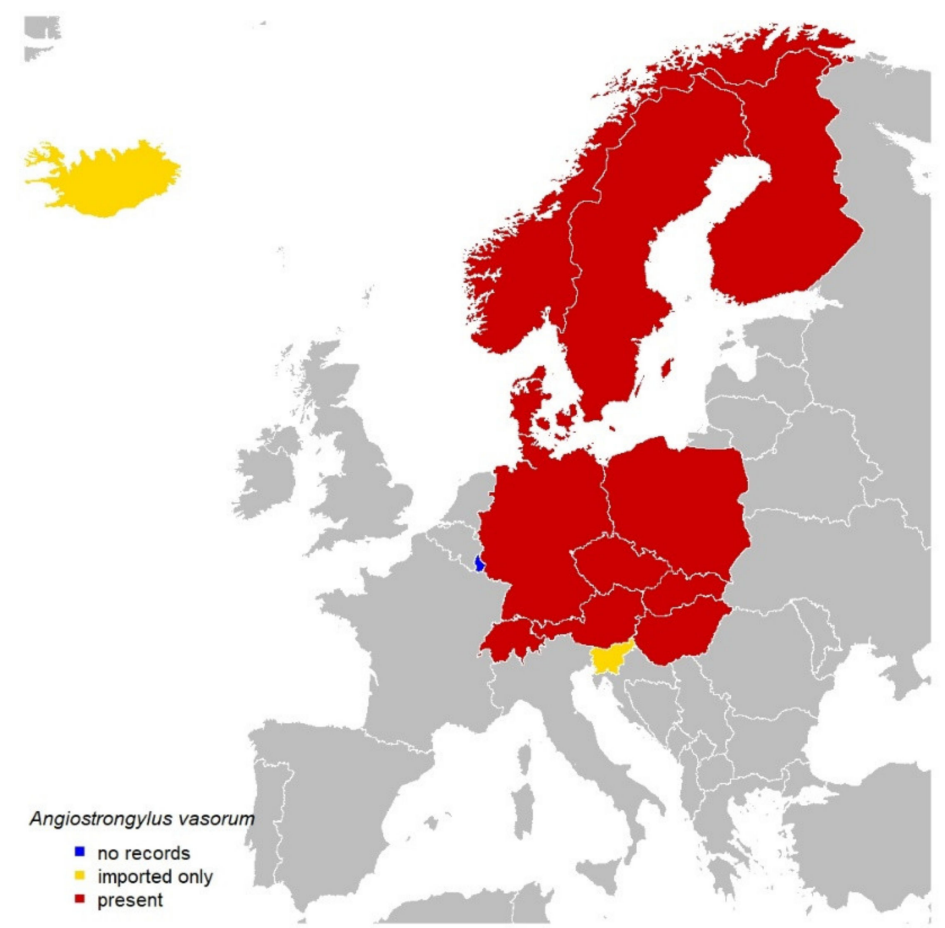

Figure 1. Distribution of Angiostrongylus vasorum in Central and Northern Europe.

\section{Dirofilaria spp.}

2.1. Central Europe

\subsubsection{Austria}

The first diagnosed cases of imported canine D. immitis infection in Austria were published in 1987 and 1988 [57,58]. The first documented canine D. repens infection and mixed dirofilarial infection in Austria, all of them imported cases, were published in 2001 [59]. Between 2000 and 2007, another six D. immitis and four D. repens infections in imported dogs were documented [60]. In a local survey in Eastern Austria in 2008, seven out of 98 canine blood samples tested positive for $D$. repens by PCR-two dogs were not reported to have had any stay abroad; this may have documented the first autochthonous infections [61]. Seven years later, a review on canine and human dirofilarial cases in Austria reported 37 dogs with $D$. repens infection (including the seven possibly autochthonous infections) and 25 dogs with D. immitis infection till 2014-a total of 62 cases within 18 years [62]. In the four following years, 84 more cases were documented till 2018, mostly D. immitis infections from imported dogs, and 10 additional dogs with coinfections of D. repens and D. immitis [63]. The most recent surveys in dogs and mosquitos in Austria focused on the possible risk for the development of new local endemic foci in and near Austrian dog shelters, and possible infections in kenneled military dogs. In total, 115 shelter dogs from 14 animal shelters located in five different Austrian states were examined in 2018 and 2019. Blood samples were screened for D. immitis, using rapid diagnostic devices (SNAP 4Dx Plus, IDEXX Laboratories, Inc., Westbrook, ME, USA), PCR, and microscopical examination for microfilariae. In total, $91.0 \%$ of the dogs originated from countries endemic for dirofilariosis. Eleven dogs (9.6\%), all originating from Hungary, tested positive for D. immitis. All mosquitos $(n=205)$ trapped in animal-shelter proximity tested negative for Dirofilaria spp. by PCR. Of these mosquitos, $98.5 \%$ belonged to a species proven or even suspected to transmit Dirofilaria spp. [64]. In the Military Working Dog Training Centre in Eastern Austria, two of 96 dogs tested positive for D. repens - one from Hungary and one originating from Austria [65]. Moreover, the first autochthonous case of D. immitis was recently documented in a cat from Burgenland [66]. Neither D. repens nor D. immitis have yet been reported from wild canids in Austria (e.g., red foxes (Vulpes vulpes)) [67]. 
The first reported human case of subcutaneous dirofilariasis in an Austrian woman was published in 1981. It was assumed that this infection had been imported from the Mediterranean area [68]. In 2006, the first autochthonous infection with D. repens in an Austrian woman near the Hungarian border was diagnosed [69]. From 1978 to 2014, 33 cases of human dirofilariasis caused by D. repens were reported in Austria (30 cases), and three cases caused by D. immitis, rising to a total of 39 cases in 2020 . Over the past four decades, incidence has markedly increased, particularly after 1998 [62,70,71]. In 2018, Austria was classified as endemic for $D$. repens (but not for $D$. immitis) with sporadic human cases [9].

D. repens in mosquitos in Eastern Austria was first detected by PCR in 2012. A low local prevalence was supposed, as two of 437 pools of collected mosquitoes close to the Hungarian border gave a positive result. All 18 individuals of one positive pool belonged to the Anopheles maculipennis (Meigen, 1880) group, and 14 individuals in the other positive pool were the Anopheles algeriensis (Theobald, 1903) species [72]. In 2013-2015, 45,848 mosquitos were sampled and analyzed for filarioid DNA by PCR. The DNA of D. repens was found in an Anopheles plumbeus mosquito close to the Slovakian border, confirming that $D$. repens is still endemic in low prevalence in Eastern Austria [73]. Potential invasive mosquitoes are competent vectors of $D$. repens and D. immitis. Aedes japonicus eggs were identified in Lower Austria, Styria, and Burgenland. Ae. japonicus was first found in Vienna in July 2017 during a routine sampling of adult mosquitoes [74]. A survey in Western Austria in 2018 found Ae. albopictus and Ae. japonicus eggs at highways and urban areas in both East and North Tyrol [75]. Ae. albopictus was first recorded in Vienna, Austria in August 2020. The species occurred in three sites within the capital city of Austria [76].

\subsubsection{Czechia}

Based on older data from the literature, the Czech Republic is regarded to be an endemic country of both $D$. immitis and $D$. repens species. However, while cases of $D$. repens are commonly reported in dogs in South Moravia, no recent reports of $D$. immitis are available. In the Czech Republic, D. immitis was only reported by Svobodová et al. [77,78]. This steeply contrasts the virtual absence of heartworm disease in the Czech Republic, and the autochthonous infection by the parasite has not been detected since then. Two recent studies [79] failed proving D. immitis in large sets of dogs examined by rapid diagnostic devices and PCR. Imported cases are sporadic and usually associated with imports of dogs from endemic regions in South Europe. Cases are not systematically reported by private vets.

Dirofilaria repens is well-known among veterinary clinicians in South Moravia, and its presence was also confirmed in mosquitoes [80]. Two studies reported human cases in the same region [81,82]. In the most recently published study, Miterpáková et al. [79] provided comparative data on distribution of $D$. repens in Slovakia and the Czech Republic, reporting $1.9 \%$ prevalence of $D$. repens in dogs from the Czech Republic. However, distribution shows a strong geographic pattern and is not homogenous; prevalence in endemic regions is higher. Dirofilaria repens is well-established in the domestic dog population in lowland areas along the Dyje and Morava rivers, extending northwards to the Kroměřiž region. This distribution corresponds well with previously diagnosed cases of human subcutaneous dirofilariosis [81,82].

\subsubsection{Germany}

In Germany, reports on imported Dirofilaria spp. infections started at the end of the last century, although no epidemiological framework was usually given. For the period of 1991-1993, Leuterer and Gothe [83] identified D. repens and D. immitis infections in three and 12 dogs, respectively, which had been imported from or traveled to endemic areas. In 1993-1996, a total of 155 imported or traveled dogs were diagnosed with filarioid infections [84-87], 10 of them with D. repens, 115 with D. immitis, and one dog with a coinfection of D. immitis and Dipetalonema reconditum. Two other dogs were mono-infected 
with $D$. reconditum, whereas for the remaining 27 Knott's test-positive dogs, native blood smears were not available for histochemical filariae identification.

In the following years, reports on the occurrence of dirofilariae in Germany stopped until the first autochthonous case of $D$. repens infection was diagnosed in a Southwestern German dog in 2004 [88]. Three years later, further autochthonous D. repens infections were reported from a sledge-dog kennel in Northeastern Germany [89], and the parasite was also identified in three of 44 Southwestern German hunting dogs with no history of traveling [90]. With these reports, prevalence data on Dirofilaria spp. in Germany gained importance, and retrospective studies including several thousand samples detected 1.1-3.1\% D. immitis antigen-positive imported or traveling dogs during 2004-2008 [91-94]. In a similar period (2004-2009), Knott's test revealed microfilariae in $6.4-7.7 \%$ of dogs; however, no species differentiation was carried out [93-95]. In a study only including traveling dogs, none of the individuals tested positive for D. immitis antigen (380 dogs) or microfilariae (223 dogs) [96].

Additionally, autochthonous $D$. repens infections stimulated research on mosquito vectors. While no Dirofilaria DNA was found in more than 80,000 mosquitos collected throughout Germany between 2009 and 2010 [97], D. repens DNA was observed in 2011 in a pool consisting of Culiseta annulata; in 2012, in two pools of An. maculipennis s.l. and each one of Anopheles daciae and Aedes vexans; and in 2016, in one Anopheles messeae pool [98-100]. Furthermore, D. immitis DNA was amplified in two Culex pipiens/torrentium pools in 2012 [100]. Both D. repens and D. immitis were found in mosquitoes originating from Southwestern and Northeastern Germany, more precisely from the federal states of Baden-Wurttemberg, and Berlin and Brandenburg, from which the autochthonous D. repens infections in dogs were also reported. Moreover, both federal states were considered to be climatically suitable for dirofilarial development in the mosquito vector and classified as risk regions for stable endemicity [101-103]. However, DNA detection in the mosquitoes just proves that they had a blood meal on a (local) microfilaremic animal, but cannot be equated with established transmission cycles. Nevertheless, Sassnau et al. [104] reported that the number of $D$. repens-infected individuals in the sledge-dog kennel increased from five in 2007 to 11 in 2012. Likewise, in the German federal state of Saxony-Anhalt, which borders Brandenburg to the west, an autochthonous infection was diagnosed in a dog in 2010 [105]; in 2014, the first German autochthonous human case was reported [106]. However, the screening of 122 red-fox and 13 raccoon-dog (Nyctereutes procyonoides) lung samples from 2009 [107], and of 1023 dog-blood, 179 red-fox-blood, and 195 red-fox-spleen samples from 2013 and 2014 [108] did not provide evidence of endemic occurrence of Dirofilaria in Brandenburg.

The most recent data on filarial infections in Germany refer again to imported or traveling pets. In dogs imported between 2007 and 2015, a prevalence of 7.3\% was found in the 178 tested individuals. Of the 13 positive dogs, eight were diagnosed with $D$. immitis, three with $D$. repens, one with $D$. reconditum, and no differentiation was performed in one dog [109]. In 133 German dogs traveling to endemic areas in 2007-2018, one dog (0.8\%) became infected with $D$. immitis [110]. Fortunately, the first data on cats living in Germany have recently become available. Of the 618 cats subjected to Dirofilaria spp. PCR included in the feline travel profile, one $(0.2 \%)$ tested positive, but no further species differentiation was conducted [111].

Overall, as the German climate allows for dirofilarial development in the mosquito vector [101-103], imported and traveling pets should be thoroughly monitored and, if positive, treated against dirofilariae to prevent the autochthonization of D. immitis and endemization of D. repens in Germany.

\subsubsection{Hungary}

On the basis of human cases reported since 1879 without confirming the identification of worms, Kotlán [112], Szénási [113] and others suspected that D. repens had been present in Hungary since the end of the 19th century. Although human dirofilariosis is not a 
notifiable disease in the country, a few dozen ocular and subcutaneous dirofilarioses were reported during the last two decades [113-115].

The first autochthonous $D$. repens infections of dogs were described only at the end of the 1990s [116,117]. In nationwide epidemiological surveys [118-120], 11.1-19.6\% of dogs and two cats were positive for $D$. repens microfilariae. Many infected dogs probably remain undetected due to the subclinical nature of the disease, and to the lack of rapid and reliable diagnostic tools. A significant cluster of microfilaremic dogs were found in the southern part of the country [120], where D. repens was the most frequent filarioid parasite in mosquito samples [121]. These veterinary reports confirmed that this nematode species is present in local dogs, representing a continuous risk of human infection in many regions of Hungary.

Heartworm infection was pathologically diagnosed only in dogs imported from the USA until 2000 [122,123]. The first autochthonous D. immitis infection was detected in a Hungarian Vizsla dog that lived in the eastern part of the country [124]. Since that time, the examinations of dogs [120,125-128], red foxes, golden jackals (Canis aureus) [129], and one ferret (Mustela furo) [130] revealed that D. immitis is endemic in the country, and the Great Hungarian Plain is hyperendemic. Mixed infections of dogs by both Dirofilaria spp. were also detected in some counties [120]. No human heartworm infection was diagnosed in Hungary.

It cannot be definitively excluded that $D$. immitis had been present in the country before the 21st century because no epidemiological surveys were carried out, and no reliable diagnostic methods were available earlier. However, it is more plausible that this filarioid species has only recently been introduced to Hungary, because neither its microfilariae nor adult worms were found in local dogs [118], and red foxes before [131]. Hunting dogs from Italy with patent heartworm infection may have acted as microfilarial reservoirs for the local mosquito population during their stay in the area, resulting in the development and transmission of infective L3 to native dogs. The role of infected wild canids arriving from neighboring countries might not necessarily be considered regarding the geographical distribution of heartworm infections in Hungary because only a few red foxes and two golden jackals were infected with a low number of worms without microfilaremia [129].

The occurrence and spread of both filarioid species in Hungary are not surprising, because the local climate and the abundance of mosquito vectors around their breeding sites offer suitable conditions for the development and transmission of these parasites. Stray dogs and dogs adopted from shelters pose an especially high risk in the epidemiology of both dirofilarioses because these animals are unlikely to receive proper examination and prevention.

\subsubsection{Luxembourg}

So far, there are no data in the literature on infections with $D$. immitis and D. repens in Luxembourg. To the authors' knowledge, no specific studies have been conducted on D. repens in Luxembourg. Between 2014 and 2020, the first serological tests were carried out, using the rapid diagnostic device to detect antibodies against $D$. immitis, among others. Serum from road-kill red foxes $(n=50)$ and raccoons (Procyon lotor) $(n=81)$ was analyzed across Luxembourg. All the tested red foxes and raccoons were negative. Given the presence of mosquitoes that can serve as vectors in Luxembourg ( $C x$. pipiens s.l. and Ae. vexans [132]), further studies should be conducted.

\subsubsection{Poland}

The first autochthonous D. repens infections of dogs were reported in Central Poland, Mazovia between 2009 and 2011 [133-136]. Since then, the number of reported cases has been growing [137,138]. Epidemiological studies carried out in 2014 in the canine population in Mazovia revealed a surprisingly high prevalence of $D$. repens, especially in dogs from suburban and rural areas [139,140]. In a study of Demiaszkiewicz [139], 462 dogs aged 1.5-14 years were examined, using the Knott method. Microfilariae of D. repens were found in the blood of dogs 
originating from the city of Warsaw and from 18 districts of Mazovia (Mazowieckie). Overall prevalence was $25.8 \%$. The highest prevalence (53.0\%) and the highest intensity of infection were found in the Radom district (Southern Mazovia). In a study [140] among sled dogs living in Mazovia sampled between 2010 and 2013, D. repens DNA was detected in 15 of 34 dogs (44.0\%). Prevalence was especially high (50.0-57.0\%) in two sled-dog kennels situated near Grodzisk Mazowiecki (Southern Mazovia).

In a nationwide epidemiological study [141], 1588 dogs were examined for dirofilariosis. Dirofilaria repens microfilariae were found in $11.7 \%$ of the blood samples of dogs originating from all 16 provinces of Poland. The highest prevalence $(25.8 \%)$ was found in Mazovia, Central Poland. About 12.0-16.0\% of dogs were positive in Eastern Poland, while much lower prevalence was noted in western and northern areas of the country.

In another study [18], 147 blood samples from cats from Central Poland, and 257 blood samples from dogs from Central, Northern, Southern, and Western Poland were collected in the period of 2013-2015. No positive dogs were noted from Kraków (Southern Poland), Wrocław (Western Poland), and Gdańsk (Northern Poland). The DNA of D. repens and/or Wolbachia was identified in two cats $(1.4 \%)$ from Central Poland. The DNA of D. repens was detected only in dogs in Mazovia (38.0\%).

In the most recent studies, the prevalence of $D$. repens in dogs from the area of Poland was about $12.0 \%(2017,2019$, and 2020$)[11,142]$. This decrease in prevalence was accompanied by increased awareness of this parasitosis, both among dog owners and veterinary practitioners, and may reflect the increased application of preventive measures during the season of mosquitoes activity [11]. The DNA of D. repens was detected in samples containing a mixture of $C x$ pipiens and Ae. Vexans mosquitoes, collected in Mazovia during the summer months of 2010-2012 [143].

The awareness and endemic status of dirofilariasis due to D. repens have risen and been confirmed only in the last decade, following the recognition of autochthonous cases in dogs and humans. The first cases of human dirofilariasis (D. repens) preceded the reports on D. repens in dogs, and were between 2007 and 2009 [144-146]. In 2012, a paper reviewing the cases of dirofilariasis was published [147]. Between 2007 and 2011, a total of 18 D. repens infections were detected in humans in Poland. Parasitic lesions were located in various parts of the body in the form of subcutaneous nodules containing single nematodes surrounded by granulation tissue (15 cases). In three cases, subconjunctival localization was found. Of the 18 described cases, 17 were in Central Poland. In this area, autochthonous infections were identified in three women who had never left Poland. The first was found in 2010 in Grójec, and the next two in 2011 in Białobrzegi and Warsaw [147]. Since that time, the number of published human cases has increased, with reports on the unusual localization or manifestation of D. repens [148-151].

In 2012, the first, likely autochthonous, case of D. immitis infection was recognized in a dog in Gdynia, Northern Poland [152]. No additional cases have been reported to date, imported or autochthonous [142,148]. Results of three epidemiological studies revealed very low or zero prevalence: in the largest study in 2014, 3094 healthy dogs from the area of Poland were tested by rapid diagnostic devices. Only $0.2 \%$ of the samples tested positive $(n=5)$, with no information on clinical signs or origin (imported vs. autochthonous) of dogs [153].

In 2019, a rapid diagnostic device test was carried out on 167 healthy sled dogs from Lithuania $(n=46)$, Latvia $(n=24)$, Estonia $(n=20)$, and Poland $(n=35)$, and on 42 healthy pet dogs from Poland, including $20 \mathrm{dogs}$ positive for $D$. repens [11]. No positive results were obtained, and no cross-reaction with $D$. repens-infected dogs was detected.

In 2020, 160 dogs from Eastern Poland were tested for Dirofilaria spp. (PCR, rapid diagnostic device). These dogs were selected on the basis of demographic features (kept outdoors, no ectoparasite prophylaxis) and the presence of clinical signs compatible with $D$. immitis infection (exercise intolerance, cough). Microfilariae of $D$. repens were identified by PCR in 20 dogs (prevalence, 12.0\%), but no samples tested positive for D. immitis [142]. 


\subsubsection{Slovakia}

In Slovakia, autochthonous canine dirofilariosis was recorded for the first time in 2005, when $D$. repens was confirmed in 13 dogs, and D. immitis in two other dogs from Bratislava and Komárno districts situated in the southwestern part of the country bordering Austria and Hungary. All infected dogs were asymptomatic [154].

In February 2007, the first monitoring covering two areas of Southwest and Southeast Slovakia was carried out. The study, encompassing 287 dogs of different age, gender, and breed, revealed microfilariae in 99 dogs, representing an overall prevalence of $34.5 \%$. In all positive dogs, $D$. repens was detected, and in six of them, coinfection with $D$. immitis was confirmed. Only in seven dogs could an autochthonous source of the infection not be unambiguously evidenced, and only in four infected dogs was a health state alternation, including dermal changes, observed. Within this research, the utilization of dogs was revealed as an important risk factor for the infection. Police, guard, and hunting dogs, with prevalence rates of $51.1 \%, 50.0 \%$, and $40.0 \%$, respectively, were more often found to be infected when compared with companion dogs (an average prevalence rate of $7.8 \%$ ). On the basis of this study, in the territory of Slovakia, highly endemic areas of D. repens were identified [155].

Between September 2007 and February 2010, a monitoring program of canine dirofilariosis aimed at working (police and military) dogs was performed in Slovakia. All 710 (591 police and 119 military) dogs from all Slovak regions were examined for Dirofilaria spp. presence. Microfilariae were detected in blood of $128(18.0 \%)$ dogs (118 police and 10 military). DNA analyses revealed D. repens mono-infection in 125 dogs and mixed $D$. repens $/ D$. immitis infection in three dogs. This survey confirmed the highest prevalence rates in southwestern parts of Slovakia identified as endemic for $D$. repens in previous study. In all infected dogs, the autochthonous origin of the infection was acknowledged. Evaluating the questionnaire data, it was highly presumable that the majority of the examined police dogs had become infected during their stay in training and breeding centers situated in the endemic area of Western Slovakia [156].

A comprehensive study summarizing research of canine dirofilariosis in Slovakia between 2005 and 2015 was published in 2016 [157]. During the 10-year study, a total of 4043 dogs from all Slovak regions were examined for Dirofilaria spp. Microfilariae were found in the peripheral-blood system of $450 \mathrm{dogs}$, representing an average prevalence of $11.1 \%$. DNA analysis confirmed D. repens mono-infection in 440 animals, mixed D. repens and $D$. immitis infection in nine dogs, and one dog was infected only with $D$. immitis. The spatial distribution of Dirofilaria spp. showed significant regional differences. The highest above-average prevalence rates were steadily recorded in the southern regions of Nitra (over $25.0 \%$ ), Trnava (18.4\%), and Košice (12.7\%). In the northern regions of Slovakia (Žilina and Prešov) bordering Poland, prevalence ranged between 2.0\% and 4.0\% [157].

An independent serological study tested newly developed commercial rapid diagnostic devices in 2015. During this study, blood and sera from 180 dogs originating from the southwestern and southeastern regions of Slovakia were investigated for the presence of microfilariae and circulating D. immitis antigen. Microfilariae were observed in 12 of 180 examined dogs, and subsequent DNA analyses confirmed D. repens in all the positive samples. In parallel, using the rapid diagnostic device, circulating $D$. immitis antigens were detected in the serum samples of five dogs $(2.8 \%)$. In two D. immitis-seropositive dogs, microfilariae of $D$. repens were also found. Regarding DNA analyses not revealing $D$. immitis presence, all five cases can be considered to be an occult form of the infection. One of the D. immitis-positive dogs came from Southeast Slovakia, and the remaining four from Komárno district, in the southwest, where D. immitis was confirmed in previous studies [158].

However, after 2015, an evident increasing trend of D. immitis cases in Slovakia has been observed. The first outbreak of heartworm infection was recorded in a dog-breeding establishment in the district of Dunajská Streda, Trnava region, near the border with Hungary. Out of 25 examined dogs (22 Newfoundlands, two Central Asia shepherd dogs, 
and one Sarplaninac), dirofilariosis was diagnosed in 18 animals (72.0\%), using several different diagnostic approaches (Knott test, DNA analysis, histochemical staining, rapid diagnostic device). Ten of the infected dogs were positive only for $D$. immitis, two for $D$. repens, and mixed infection was confirmed in six dogs. Occult D. immitis infections without circulating microfilariae were recorded in six dogs. No dogs showed clinical signs of heartworm disease. Regarding travel history, the autochthonous origin of the infection could unambiguously be confirmed in seven dogs [159].

The first registered fatal case of canine heartworm disease was recorded in 2019. In two seven-year-old Tibetan Mastiff siblings from the Košice region, Southeast Slovakia, raised in the same household, D. immitis was confirmed. The course of the infection in the two dogs markedly differed. Although the female dog manifested no health-status alternation, the male dog exhibited severe clinical signs, including elevated creatinine and urea levels, increased liver hyperechogenicity, and hepatomegaly. The dog died five days after hospitalization. Subsequent postmortem examination revealed adult D. immitis worms in the right heart ventricle [160].

The most recent epidemiological study on canine dirofilariosis in Slovakia was carried out in late 2019. Within the study, 644 randomly selected dogs were examined for the presence of Dirofilaria spp. Microfilariae were present in 68 blood samples with an overall prevalence of $10.6 \%$. Subsequent DNA analysis confirmed D. repens mono-infection in $38(5.9 \%)$ dogs, a single D. immitis infection in $21(3.3 \%)$ animals, and both Dirofilaria species were detected in nine $(1.4 \%)$ samples. These data indicate an increasing number of D. immitis cases in Slovakia, previously considered to be endemic only for D. repens [79].

In Slovakia, besides dogs, the presence of $D$. repens DNA was confirmed in the spleen samples from one individual of beech marten (Martes foina) and red foxes [161,162]. The results of the study showed 105 of the 183 examined red foxes being infected, representing an overall prevalence above $57.0 \%$.

Regarding Dirofilaria vectors, research focused on mosquitoes is still in its infancy and mostly regionally oriented in Slovakia. The first screening for dirofilariosis in mosquitoes was performed in 2013 in Eastern Slovakia, and showed that the Ae. vexans species was incorporated into the life cycles of both D. repens and D. immitis $[163,164]$. During the next xenomonitoring carried out in Bratislava, Western Slovakia, D. repens was detected in An. Messeae, An. maculipennis, and Cx pipiens complexes, and D. immitis in Coquillettidia richiardii and $C x$. pipiens pipiens. Both dirofilarial species were also found in Ochlerotatus sticticus [165].

The first case of human dirofilariosis in Slovakia (at that time Czechoslovakia) was reported in 1992, when the presence of a wormlike formation in the vitreous body of a patient was discovered at the ophthalmological examination. Nevertheless, retrospective view of this case reveals some doubts about the diagnosis [166]. The first autochthonous and unambiguously confirmed case of human dirofilariosis was reported in 2007, two years after the first finding of dirofilarial parasites in dog population. Since then, between 2007 and 2020, 23 cases (subcutaneous, ocular, and pulmonary) were confirmed in Slovakia. In all cases, D. repens was validated as the causative agent $[167,168]$.

\subsubsection{Slovenia}

The first case of D. immitis in Slovenia was recorded in 1986. A clump of nematodes was found in the right ventricle and pulmonary artery of only one dog. The researchers hypothesized that a factor in the spread of dirofilariosis in Slovenia might be dogs imported from Italy and tourism flows with pets, which led them to expect an increase in the number of infected dogs. They cautioned that, with these epidemiological data, human cases should also be expected. They assumed that, since $D$. repens was present in neighboring Italy, its occurrence in Slovenia should also be expected [169]. The following year, the first case of the subcutaneous form of dirofilariosis in a red fox, caused by D. repens, was described in Slovenia by Brglez and Verbančič [170]. They found a high number of mature and juvenile parasites in a red fox killed on the road. In 1998, a human case of subcutaneous 
dirofilariasis was described in the occipital region of a 61-year-old Slovenian woman, caused by $D$. repens. The authors identified a trip to Canary Islands, Spain as the probable site of infection, because the subcutaneous tumor was diagnosed seven months later. The authors suggested that human cases of dirofilariasis are most likely under-reported, as many cases are undiagnosed or unpublished [171]. Currently, there is no officially reported number of human cases of dirofilariasis in Slovenia. A study of imported canine filarioid infections in Germany from 2008 to 2010 reported that D. repens was found in a dog imported from Slovenia. Although no prevalence studies of dirofilariosis in dogs were available, the authors considered Slovenia to be endemic for D. repens [92]. Currently available data from the Institute of Microbiology and Parasitology at the Veterinary Faculty of the University of Ljubljana show that, out of 400 blood samples from dogs acquired and tested for Dirofilaria spp. between April and October 2018, only two were positive for this parasite (Vergles Rataj, personal communication).

\subsubsection{Switzerland}

Due to the perceived spread of D. immitis in the USA in the 1960s [172], the presence of the parasite in countries neighboring Switzerland, such as Italy $[173,174]$ and France $[175,176]$, and the report of an imported case in Germany [177], in a review article, Thun (1975) alerted Swiss veterinarians about the relevant aspects of $D$. immitis infections in dogs [178]. At the end of the 1980s, the first imported cases of canine dirofilariosis were diagnosed at the Institute of Parasitology, University of Zurich by the detection of circulating antigens and characterising microfilariae by acid phosphatase activity. The first clinical case of D. immitis dirofilariosis was diagnosed at the Animal Hospital of the Veterinary Faculty in Zurich, in a Siberian husky living in Milan (Italy) [179]. While clarifying the situation of another husky living in the same kennel, this dog was negative for D. immitis but positive for microfilariae of $D$. repens, thereby representing the first diagnosed and imported case of cutaneous dirofilariosis in a dog in Switzerland. Moreover, two stray dogs of unknown origin were diagnosed positive for D. immitis in Ticino, Southern Switzerland, and several dogs originating from the Mediterranean basin were diagnosed positive for D. immitis or D. repens at the Institute of Parasitology in Zurich [179]. In a follow-up study in which 217 stray dogs and 154 unwanted dogs from Ticino had been investigated, microfilaria were isolated from the blood of four dogs; these were confirmed as D. immitis by morphology and antigen detection. In all these cases, the import of dogs from Italy could not be excluded, thus not confirming the autochthonous presence of Dirofilaria spp. in the country. However, on the basis of further mentioned cases diagnosed close to the border with Italy and in suitable temperatures for the development of D. immitis in mosquitoes in the same area, the establishment of the parasite was anticipated [180]. In fact, when testing 479 blood samples from that region, three $(0.6 \%)$ and eight $(1.6 \%)$ dogs were positive for $D$. repens and D. immitis, respectively. For a single dog, local transmission was confirmed by excluding traveling abroad by the owner [181]. The investigation of dog samples from both sides of the borders, Switzerland and Italy, confirmed higher prevalence in Italy, while contemporaneously identifying four dogs positive for $D$. repens $(\mathrm{n}=2)$ and/or D. immitis $(\mathrm{n}=3)$ from Ticino. Due to the limited number of cases in Southern Switzerland despite the widespread presence of suitable vectors [182,183], Southern Switzerland is considered as the border of the endemic area of both Dirofilaria spp.; therefore, prevention measures were recommended and are currently regularly implemented. These include the treatment of all infected dogs with microfilariae in order to decrease the risk of transmission [184]. To our knowledge, no autochthonous case of dirofilariosis north of the Alps was determined (Deplazes, personal communication). In fact, most of the cases have a clear history of import [185] or traveling.

Similarly, three human patients of dirofilariasis diagnosed in Swiss hospitals originated from abroad (India) [186], had a travel history to the Mediterranean area [187] or to Southern Switzerland and Northern Italy [188]. Different organs were affected: the epididymis in the first case, pulmonary nodules in the second, and the subconjuctival tissue 
in the third patient. Two were confirmed as caused by D. repens, and one was attributed to D. immitis (pulmonary nodules), but not confirmed by laboratory techniques.

\subsection{Northern Europe}

Results of a questionnaire study among veterinarians showed that $11.0 \%$ of the participating veterinarians who were practicing in Nordic countries reported having seen dogs with $D$. immitis infection, $3.0 \%$ reported having seen dogs with $D$. repens infection in 2016, and a majority of the cases were reported to be in dogs with a history of travel or import [56]. The situation was very different to that in the nearby Baltic countries, in particular regarding $D$. repens: almost a fourth of veterinarians practicing in Baltic countries reported having seen $\operatorname{dog}(\mathrm{s})$ with $D$. repens infection, and none of these had a history of travel or import [56]. Dirofilaria repens emerged in the Baltic countries in 2008-2012 and became endemic $[11,13,189,190]$.

\subsubsection{Denmark}

There are no published reports of Dirofilaria spp. in animals in Denmark, while a human case of $D$. repens in a 39-year-old woman was reported in 2014. However, the woman was likely infected on Crete [191]. The vectors of both D. repens and D. immitis are present in Denmark (Huus Petersen, personal communication) and, during a period of 15 years, two locations in Denmark reached in July at least once the 130 heartworm development units (HDU, the total environment heat required for the development of Dirofilaria from microfilaria to infectious L3 within the mosquito), but none of them reached the $130 \mathrm{HDU}$ based on average temperature [192]. There are no published records of surveillance studies on dirofilariosis in wild-living canines from Denmark, and to the authors' knowledge, no surveillance studies have been performed.

\subsubsection{Finland}

There is one published case report of autochthonous human D. repens infection from Southeast Finland from 2015 [193]. There are no published reports of autochthonous $D$. repens nor $D$. immitis infections in dogs from Finland. The first $D$. repens finding in an imported dog was in 2014 [193]. Dirofilaria ursi is present in brown bears (Ursus arctos) in the eastern part of Finland, but no human cases have been reported [193,194]. During a period of 15 years several places in Finland reached in July at least once the $130 \mathrm{HDU}$, but none of them reached the 130 HDU based on average temperature [192].

\subsubsection{Iceland}

There are no reported cases of $D$. immitis or $D$. repens from Iceland. Moreover, competent mosquito vectors are not present on Iceland.

\subsubsection{Norway}

The first published case report, published in 1991, of apparently imported human D. repens infection in the Nordic countries was from Norway [195]. Dirofilaria repens infection was reported in dogs imported to Norway from South Africa [196] and Hungary [197]. Dirofilaria immitis was also reported in imported dogs [198]. During a period of 15 years, some places in Southern Norway reached in July at least once the $130 \mathrm{HDU}$, but none of them reached the $130 \mathrm{HDU}$ based on average temperature [192].

\subsubsection{Sweden}

Endemic cases of Dirofilaria spp. have not been found in Sweden to date, but in addition to $A$. vasorum, these infections are notifiable, and the following cases were reported during the last five years: three cases in 2015, two cases in 2016, no cases in 2017, two cases in 2018, and seven cases in 2019 [199,200]. Unfortunately, Dirofilaria spp. infection is reported at the genus level, i.e., the record of notified cases is not discriminating between D. immitis and D. repens, so it is not possible to describe which of the two parasites has been 
diagnosed more often. According to the most recent studies of the northward expansion of Dirofilaria infection in Europe, during a period of 15 years some places in Sweden reached in July at least once the $130 \mathrm{HDU}$, but none of them reached the $130 \mathrm{HDU}$ based on average temperature [192].

\section{Angiostrongylus vasorum \\ 3.1. Central Europe \\ 3.1.1. Austria}

A. vasorum was detected in gastropods in Austria in two studies [51,201]. One study investigated their occurrence in 1320 gastropods collected in the Austrian provinces of Styria, Burgenland, Lower Austria, and in metropolitan Vienna. Metastrongyloid larvae were microscopically detected in 25 samples, and sequence analysis confirmed the presence of $A$. vasorum in one slug (Arion vulgaris; $0.1 \%$ ) [51]. The first cases of canine angiostrongylosis reported in Austria were imported from endemic areas of France [202,203]. In a retrospective study, 1040 fecal samples of Austrian dogs were analyzed by using the Baerman method [204]. L1 of A. vasorum were documented in 1.3\% of the dogs originating from Vorarlberg (Western Austria), Styria (Southeastern Austria), Lower Austria, and Vienna (Northeastern Austria). Moreover, 1.2\% of 1279 dogs were positive for specific antigens, and $1.5 \%$ for specific antibodies at serological tests. These dogs originated from all Austrian provinces (with the exception of Burgenland), namely Lower Austria, Upper Austria, Vienna, Styria, Carinthia, Salzburg, and Tyrol [204]. However, although helminth L1 antigens and antibodies were reported at many locations, these data indicate a very low prevalence of $A$. vasorum in dogs in Austria [204].

\subsubsection{Czechia}

The occurrence of $A$. vasorum was not surveyed on larger sample set. A relatively recent study by Hajnalová et al. [205] found 4.7\% of dogs (nine of 193) to be positive for circulating antigen by ELISA. L1 were detected in one of the 253 examined dogs. Infection is sporadically detected in necropsied red foxes; however, systematic research is not conducted. On the basis of feedback from small-animal practitioners, A. vasorum is not yet considered an issue, though conditions for the transmission are ubiquitous.

\subsubsection{Germany}

The first reference on angiostrongylosis in Germany describes phagocytosis of the parasite by giant cells in a histological section of a five-year-old royal poodle suffering from verminous pneumonia caused by A. vasorum, necropsied in 1964 [206]. Shortly thereafter, angiostrongylosis was reported in a four-year-old dachshund that was euthanized in 1965, due to incurable heart damage [207]. In both cases, nothing is mentioned about a possible travel history, so it remains unclear whether the dogs had traveled or not. A few decades later, in 2003, another case was diagnosed in a Southern German dog living on the border to Switzerland. On the basis of anamnestic data, the authors considered an autochthonous infection [208], whereas subsequently published cases reported an import from or travel history to France, Italy, or Portugal [209,210].

The first German prevalence data are available from 1999 to 2002 , where A. vasorum L1 were found in $0.3 \%$ of diagnostic dog fecal samples [211]. In the following years, prevalence increased to $0.9 \%$ in 2010 and $1.6 \%$ in 2016 [212,213]. A. vasorum occurrence spatially clustered in Southwest Germany. This pattern was also observed in a seroprevalence study resulting in $0.5 \%$ antigen-positive and $2.3 \%$ antibody-positive dogs; however, the vast majority of samples originated from West German federal states [214]. In a study conducted in Central Germany, 1.2\% clinically healthy sheep-herding dogs tested coproscopically positive [215].

In dogs with clinical signs indicative for lungworm infection, $A$. vasorum-positive fecal samples ranged between $1.1 \%$ and $7.4 \%$ [216-219]. The most recent study on lungwormsuspected dogs evaluating more than 12,000 fecal samples reported both a significant 
increase in $A$. vasorum prevalence, and an accumulation of positive dogs in Northeast and Southwest Germany, indicating a potential spread or awareness of the parasite (from these parts of Germany, autochthonous $D$. repens infections were also reported; see above section). A study in red foxes confirmed the endemicity of $A$. vasorum in Northeast Germany by DNA detection in $9.0 \%$ of the lungs [107]. Nevertheless, the prevalence of $27.0 \%$ in red foxes in Rhineland-Palatinate [220] still reveals Southwest Germany to be a highly endemic region [221].

Lastly, the increasing $A$. vasorum prevalence and the accumulation cluster in Southwest and Northeast Germany raise the question of what happens in the intermediate parts of the country. New data are desirable, especially as samples from these intermediate regions were underrepresented in all studies evaluating geographical distribution.

\subsubsection{Hungary}

In 1960, Kotlán [222] first mentioned the sporadic occurrence of $A$. vasorum in a dog and red foxes in Hungary. A few decades later, angiostrongylosis was found in red foxes $[129,131]$ and golden jackals [49], indicating that wild canids play an important role in the distribution and establishment of this parasitic species, since the mollusc intermediate hosts are broadly distributed in Hungary [223]. The first cases of dogs infected by A. vasorum were two asymptomatic animals kept in gardens close to the Croatian border, where five slugs were found carrying larvae of this parasitic species [224]. These infections were considered autochthonous because both dogs were born where they lived and never left their villages. In a large-scale combined serological survey of 1247 pet dogs, 1.4\% of them were positive by two ELISA [225]. A considerable number of cases were observed in Budapest, and in the southern part bordering Croatia. The results of this serological survey confirmed the endemic occurrence of $A$. vasorum in dogs in different parts of Hungary.

\subsubsection{Luxembourg}

There are no reports in the literature on the presence of A. vasorum in Luxembourg. In a current study (Heddergott, personal communication), 27 fresh road-kill red foxes, mainly from the eastern part of the country (administrative districts Diekirch, Echternach, and Grevenmacher), were examined for infection with A. vasorum. At necropsy, the heart, lungs, and adjacent vessels and from the rectum of the cadavers were taken. The genetic diagnosis of fecal samples was performed by SAF technique, Giardia and Cryptosporidium coproantigen ELISAs, and by duplex copro-PCR. All examined red foxes were negative.

\subsubsection{Poland}

The first finding of A. vasorum in Poland (northeast, Augustowska Primeval Forest) was in red foxes in 2013 [226]. Adult nematodes were found in 4/76 red foxes (5.0\%). In 2014, the first clinical case was described in a dog in Lublin (Eastern Poland) [227].

In a large epidemiological study conducted in 2013, the sera of 3345 healthy dogs from veterinary clinics all over the country were tested; specific antibodies against $A$. vasorum were found in 60 animals (1.8\%), and parasitic antigens in 43 dogs (1.3\%) [228].

In another study, $A$. vasorum L1 were detected by using coproscopic methods in $7.0 \%$ of the 58 fecal samples of grey wolves from the Bieszczady Mountains (Southeast Poland) [229].

\subsubsection{Slovakia}

The first autochthonous case of canine angiostrongylosis in Slovakia was officially reported in 2013 in a seven-month-old Maltese pinch dog in Košice, southeastern part of the country [230]. The physical examination revealed no remarkable clinical signs in the patient [230].

In the same year and location, $A$. vasorum was diagnosed in an 18-month-old Bernese mountain dog. The infection was accompanied by serious clinical signs and almost fatal course; inter alia, irritating cough, dyspnea, vomiting, bilateral scleral bleeding, and acute 
physical collapse were observed in the patient. The infected dog excreted L1 in high numbers (more than $800 \mathrm{~L} 1$ were counted in $10 \mathrm{~g}$ of feces) [231].

On the basis of these first cases, a serological survey was conducted to assess the current distribution of A. vasorum in the dog population of Slovakia. Serum samples from 225 dogs originated from 22 districts were tested by ELISA for the presence of circulating A. vasorum antigens and for the detection of specific antibodies. Fourteen $(6.2 \%)$ dogs were positive in at least one ELISA; seven dogs (3.1\%) were only antibody-positive, four animals $(1.8 \%)$ were positive only for circulating $A$. vasorum antigen, and three individuals $(1.3 \%)$ were positive in both ELISAs. Seropositive dogs came from different regions with the highest accumulation of the cases in Southwest Slovakia. Three dogs positive for circulating antigen and specific antibodies originated from Bratislava region on the border with Austria [232].

Another survey based on the Baermann technique and modified-flotation method revealed that 14 of 339 (4.1\%) examined dogs had been infected by A. vasorum [233].

A rare case of canine angiostrongylosis was described in 2019, when $A$. vasorum was detected in the anterior eye chamber of an 18-month-old beagle from the northeastern part of Slovakia. The dog's feces were examined for the presence of L1 with negative results, but the final diagnosis was confirmed by DNA analyses and sequencing [234].

The circulation of $A$. vasorum in populations of free-living carnivores was confirmed in two independent surveys. Between 2014 and 2016, 571 fecal samples from red foxes, originating from all Slovak regions, were investigated for $\mathrm{L} 1$ of $A$. vasorum. The parasitic presence was confirmed in 31 animals, representing an average prevalence of $4.4 \%$. In five positive red foxes, infection with Crenosoma vulpis was also diagnosed. Within this study, the potential influence of selected environmental variables on the occurrence of $A$. vasorum was quantified, using logistic regression. The distribution of $A$. vasorum showed typical spatial clustering and occurred in endemic foci mainly in the eastern part of Slovakia. A cluster of $A$. vasorum infection foci was found in both humid and the driest areas of Slovakia. A multivariable model for A. vasorum also revealed tendency of the parasite to prefer areas with higher shares of arable land and lower proportions of forests [48].

Besides the red fox, the grey wolf (Canis lupus) is considered to be another suitable reservoir host for A. vasorum. Between 2015 and 2016, the first systematic parasitological examination of the wolf population living in two national parks and in one protected landscape area of Slovakia was carried out. Overall, 256 wolf fecal samples were gathered and examined for $A$. vasorum presence, using the modified-flotation method with zinc sulfate solution. Angiostrongylus vasorum L1, subsequently confirmed by DNA analysis, were detected in two samples, in one wolf originated from Tatra National Park and in one individual from Pol'ana Protected Landscape Area [235].

\subsubsection{Slovenia}

In several dozen samples per year sent to the Institute of Microbiology and Parasitology at the Veterinary Faculty of the University of Ljubljana for diagnosis of lungworms, A. vasorum was diagnosed only once in a hunting dog imported from Hungary, whose cause of death was angiostrongylosis (unpublished data).

\subsubsection{Switzerland}

In Switzerland, the first cases of $A$. vasorum were reported from a dog-breeding station in Zurich in 1968 [236], but only decades later did Staebler et al. [208] report five dogs infected with $A$. vasorum in the northern part of Switzerland, and three dogs coming from Southern Ticino, all diagnosed between 1999 and 2004. In addition, in 2001, two infected red foxes originating from the region of Basel were reported [237].

By means of serological tests that were developed for circulating antigen and specific antibody detection [238], in a first epidemiological study with more than 4000 sera an overall seroprevalence of $1.0 \%, 2.8 \%$, and $3.1 \%$ for dogs positive in both ELISAs, in antigen ELISA and antibody ELISA, respectively, was detected. Spatial analysis showed that 
positive dogs were distributed over large areas of the country, and a cluster of antibodypositive dogs in the northern area of Switzerland bordering Germany was identified [239]. Approximately in the same period, a grid-cell-based noninvasive fecal-sampling scheme for red fox samples indicated an overall prevalence of $8.8 \%$, and revealed that land use and altitude affected prevalence rate [240]. Both dog and red-fox studies showed that prevalence rates increased with decreasing altitudes (and corresponding temperature variations), and that trend prevalence was higher in and around the first known endemic foci where $A$. vasorum was initially present. Investigating the Swiss red-fox population further, it was hypothesized that the transmission of $A$. vasorum among red foxes started to increase at the end of the 20st century due to the higher density of red foxes [241], increasing contamination of the environment, thereby infecting intermediate hosts and dogs. In fact, working up blood samples back from the past three decades from throughout the country, a drastic $A$. vasorum emergence from $2.4 \%$ to $62.0 \%$ was identified, reaching currently regional prevalence of more than $80.0 \%$ [4]. In particular, around 2000, a marked increase in seropositive red foxes correlated with the first accumulations of cases of canine angiostrongylosis. Locally, prevalence based on red-fox necropsy increased fourfold in only six years [4]. A group of captive meerkats (Suricata suricatta), housed in such a locally known highly endemic area was $A$. vasorum-positive, with L1 excretion in seven of 17 animals. Their natural infection was supported by the identification of positive mollusc intermediate hosts in their immediate surroundings [37]. The very first global identification of a naturally occurring infection with A. vasorum in a cat may trace back to a highly endemic area; however, because cats do not become patent, such infections are highly challenging to diagnose intra vitam and are possibly underestimated [41]. Overall, these data evidenced the important role of red foxes as reservoir hosts, and also helped to understand the increasing number of dog cases along with significant prevalence in the red fox populations in other European countries in the last decade.

\subsection{Northern Europe}

\subsubsection{Denmark}

In Denmark, the first case of $A$. vasorum was described in 1983 in a five-year-old Cairn terrier from North Zealand [242]. The dog was euthanized due to bronchitis; at necropsy, A. vasorum were observed in the arteria pulmonalis, and the smaller arteria and arterioles. L1 were also demonstrated in a fecal sample [242]. The dog had visited Southern France several times and probably acquired the infection there. The next case was observed in 1989, also in a dog from North Zealand that had also been visiting France (Huus Petersen, personal communication). In 1990/1991, clinical cases were diagnosed in a considerable number of Danish dogs, none of which had ever been outside Denmark, but all from North Zealand [243,244]. In the same period, 12 of 15 adult red foxes from North Zealand were found positive for $\mathrm{L} 1 \mathrm{in}$ the feces, and/or adult $A$. vasorum in the right atrium of the heart and the pulmonary arteries [245]. The parasite had not previously been detected in a1973 parasitological survey of 100 wild red foxes from Denmark [246]. Since then, North Zealand has been a hyperendemic focus of $A$. vasorum in red foxes and domestic dogs for decades [245,247], while the parasite was either absent or with low prevalence in red foxes in the remainder of Denmark (0.0-1.1\%) [247-249]. The latest study of A. vasorum in Denmark was conducted in 2017/2018 on 1041 wild animals, including 367 red foxes [40]. The study showed that $A$. vasorum prevalence in red foxes originating from the remainder of Zealand (37.0\%) was now similar to the prevalence in the hyperendemic North Zealand (37.5\%). This indicates that the hyperendemic area expanded to include all of Zealand [40]. In Jutland, the prevalence of $A$. vasorum in red foxes was much lower (1.7-2.3\%), but higher than what had previously been reported. This indicates that $A$. vasorum is spreading in the red-fox population both in New Zealand and in Jutland. In addition, raccoon dogs (15 of 476) and polecats (Mustela putorius) (7 of 14) constitute a reservoir for A. vasorum in Jutland with prevalence ranging from $2.1 \%$ to $3.6 \%$ and from $50.0 \%$ to $100.0 \%$, respectively. 


\subsubsection{Finland}

Angiostrongylus vasorum appears to be multifocally present in Finland. Two autochthonous A. vasorum findings in dogs, from 2014 and 2017, have been described in detail [53]. There is also a single case report of imported $A$. vasorum infection in a domestic $\operatorname{dog}$ [250]. A questionnaire survey among veterinarians indicated that a limited number of more domestic dogs with the infection would have been seen in the country, including a third autochthonous case [53]. The parasite was described in red foxes in the 1960s [251], and in a single red fox in the southern part of the country more recently [252].

\subsubsection{Iceland}

A dog, a Siberian husky, imported in December 2017 to Iceland from Switzerland, was reported to be positive for $A$. vasorum [253]. In this study, more than 5000 imported dogs had been examined since 1989, and only this single A. vasorum case was found.

\subsubsection{Norway}

No autochthonous $A$. vasorum findings have been reported from domestic dogs from Norway. The parasite was detected in red foxes in the country for the first time in 2016, and further findings were reported from active surveillance [254,255]. In 2019, A. vasorum was detected also in Northern Norway [256].

\subsubsection{Sweden}

The first endemic case of $A$. vasorum was described in Sweden in 2003, when a dog from the island of Sydkoster, province of Bohuslän, was euthanized, and the diagnosis was confirmed at necropsy [257]. The demonstration of the endemic presence of the parasite came from the finding of parasitic L1 in two fecal samples from red foxes from Sydkoster; later, A. vasorum adults and L1 were found at necropsy in a dead red fox coming from the same island [257]. During 2011-2015, the parasite was detected in $0.7 \%$ of fecal samples ( $n=20$ of 2882 samples) analyzed with the Baermann test at the National Veterinary Institute (SVA, Uppsala, Sweden); these findings came from different parts of the country [54]. During the same period, A. vasorum was found at necropsy in red foxes, representing an occurrence ranging between $0.3 \%$ and $1.4 \%$ of necropsied red foxes, but the necroscopic investigations were not aimed at detecting specifically A. vasorum [54]. Regarding other potential final hosts, $A$. vasorum was not found in grey wolves $(\mathrm{n}=20)$ hunted in Sweden [258]. A large national seroprevalence study was performed on serum samples collected between 2013 and 2014, and it showed that $0.1 \%$ of dogs were positive in both parasite antigen tests and antibody tests [54]. Since the disease is notifiable in Sweden, the following cases were reported during the last five years: 11 cases in 2015, eight cases in 2016, no cases in 2017, two cases in 2018, and two cases in 2019 [199,200].

\section{Factors Influencing the Prevalence and Establishment of D. immitis and D. repens}

According to Simón et al. [15], the transmission of D. immitis and D. repens is limited by two main preconditions: (i) the presence of a mosquito species capable of transmitting the parasite and (ii) the presence of a minimal number of dogs infected with adult nematodes shedding microfilariae. The distribution of $D$. immitis and D. repens is further influenced by human behavior (e.g., the housing conditions and travel activity of dogs, and imports), and climatic conditions allowing the presence of competent mosquito vectors and larval development [15]. Although infections with D. immitis and D. repens were documented in various wild canids, wildlife seem to play a limited role in the spread of these pathogens.

Three factors majorly impacted the prevalence, distribution, and establishment of populations of D. repens and D. immitis in Central and Northern Europe:

\subsection{Dogs Staying Outside Overnight}

Currently, human behavior is the major factor for the spread or import of Dirofilaria spp. in Central and Northern Europe. Both D. immitis and D. repens are frequently 
imported to non-endemic countries from endemic countries (e.g., stray dogs from Spain and Greece) [64]. The introduction of microfilaremic dogs to non-endemic areas may lead to local autochthonous outbreaks such as in military-dog facilities with kennel keeping [65]. The way of dog keeping majorly impacts the establishment of populations of these parasites. Stray dogs and cats, and private kennel keeping are not (very) common in Central and Northern Europe. Kennel or outdoor keeping of military, hunting, and sled dogs and keeping dogs in animal shelters are common practices in certain regions in Central and Northern Europe. In several Central European countries, more than $30.0 \%$ of the dogs are estimated to stay outside overnight (Figure 2), and so they are at a higher risk for mosquito bites compared to dogs staying inside. In addition, nocturnal house mosquitoes of the $C x$. pipiens complex are competent vectors for D. immitis and D. repens, and those are the mosquitoes with the highest abundance in the vicinity of humans.

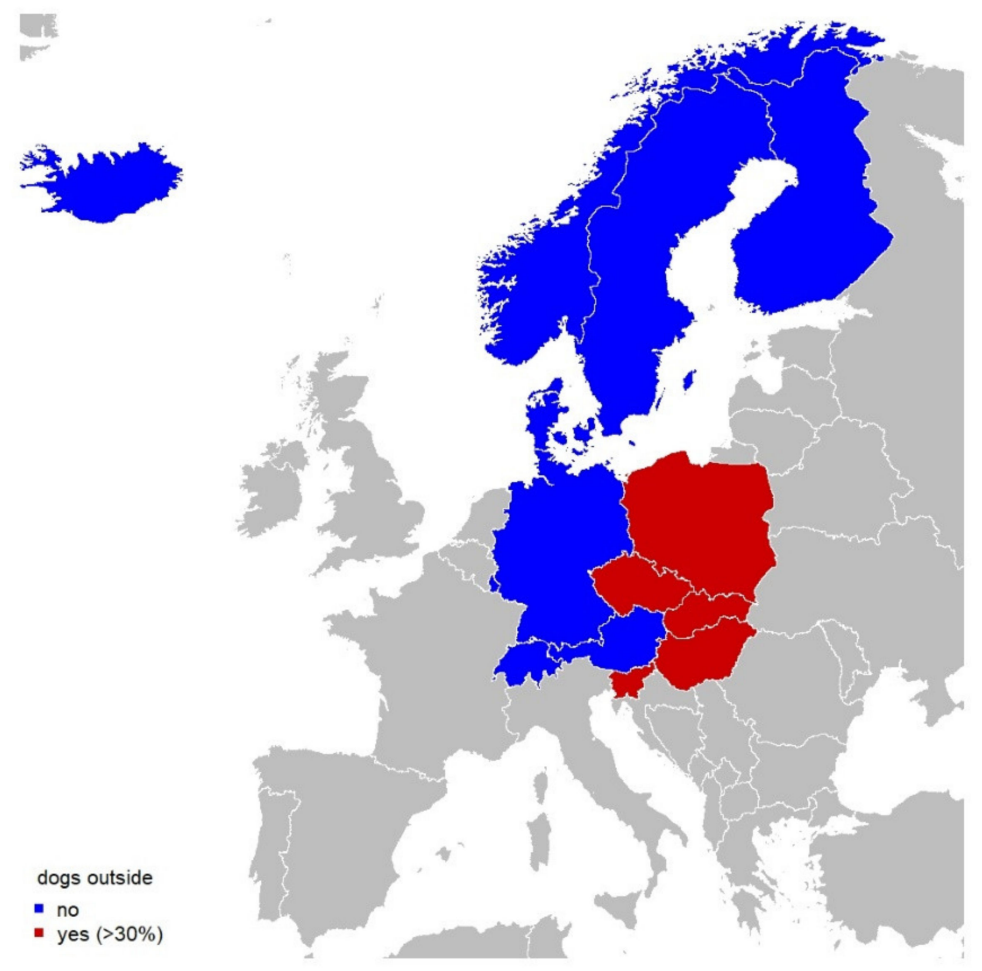

Figure 2. Dogs staying outside overnight (no = uncommon that dogs are kept outside overnight; yes $\geq 30 \%$ of dogs stay outside overnight).

\subsection{Diurnal Vector Activity}

Diurnal vector activity: More than 60 mosquito species are vectors of $D$. immitis or D. repens. During blood meals, microfilaria are ingested, move to the Malpighian tubes, and L3 move to mouthparts and enter the labium (after passing the cibarium). Vector competence can be proven in laboratory studies [259]. At xenomonitoring studies where pooled mosquitoes are screened by PCR, vector competence can only be estimated [73]. Findings of L3 in caught wild mosquitoes (microscopically and not DNA in an entire mosquito only) can indicate vector competence. Furthermore, the molecular analysis of the head or thorax vs. abdomen can indicate vector competence $[260,261]$. However, laboratory suitability does not automatically mean that infections in the field occur frequently. Mosquito ecology and preferences differ from species to species (such as different habitats or blood-meal preferences) [262,263].

Several species of the Aedes, Culex, and Anopheles genera were demonstrated as competent vectors $[15,262,264]$. Synanthropic mosquito species with high abundance at human settlements might be the most important vectors for the establishment of parasite populations. In Central and Northern Europe, house mosquitoes of the $C x$. pipiens complex fill 
this gap. These mosquitoes have a nocturnal activity pattern [265], so dogs staying outside overnight are more prone to these mosquitoes than those staying inside are.

In recent decades, several potential invasive mosquito species such as Asian tiger mosquito Ae. albopictus were introduced to Europe, primarily through the transport of goods (such as used tyres) [266]. In Southern Europe, the tiger mosquito rapidly established, and this invasive species is spreading northwards [267]. The tiger mosquito has already established in certain regions in Central Europe, and is regularly reintroduced in others (Figure 3) [75].

The Asian tiger mosquito is both a competent vector for D. immitis and D. repens, and an annoying day-active biter that outcompetes $C x$. pipiens s.1. [268]. The establishment of populations of tiger mosquitoes would allow for the transmission of microfilariae to dogs during daytime and increase the risk of dogs to acquire an infection. The increased probability of Dirofilaria infections in areas where tiger mosquitoes established was reported from Italy $[269,270]$.

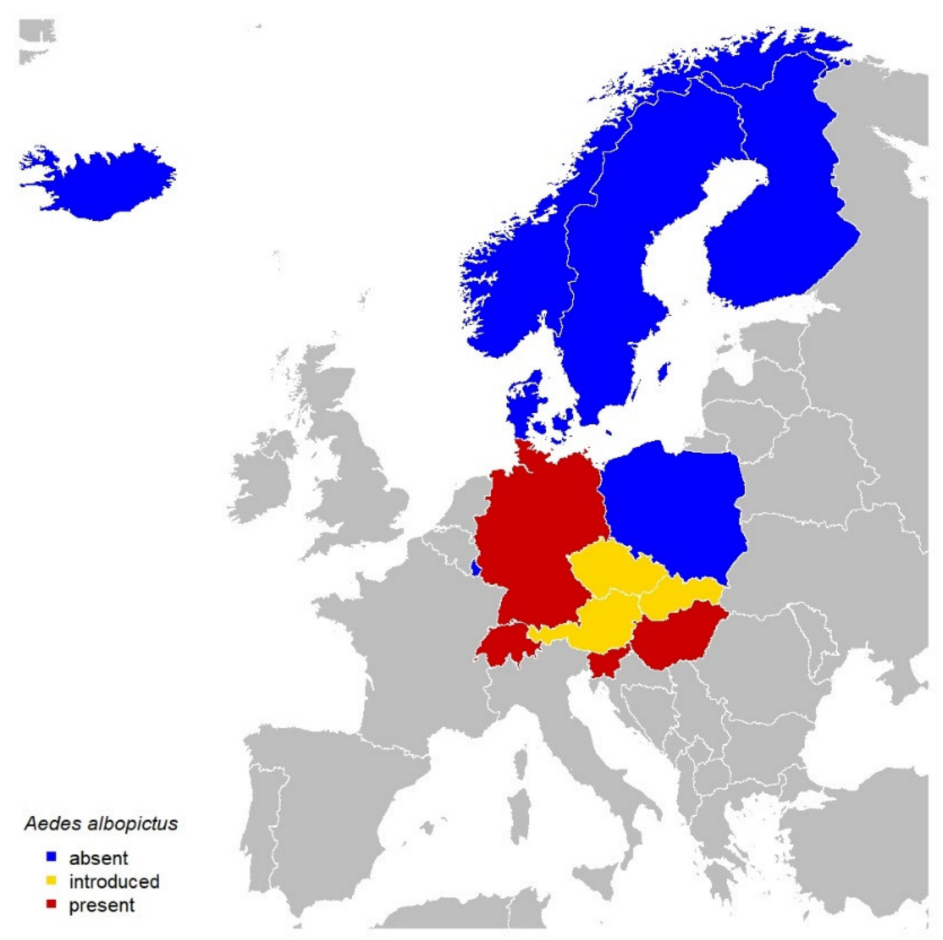

Figure 3. Distribution of Asian tiger mosquito (Aedes albopictus) in Central and Northern Europe according to the ECDC in March 2021 (introduced, no stable populations known yet; present, established populations at certain areas in the country). For detailed and updated information, please visit https:/ / www.ecdc.europa.eu/en/disease-vectors/surveillance-and-disease-data/mosquitomaps (accessed on 14 August 2021).

\subsection{Climate Change}

Temperature has an important influence on the development of mosquito vectors and parasites. On the one hand, longer warm periods per year allow for more generations of parasites and vectors per year. On the other hand, increasing temperatures allow for a faster development from eggs to adult mosquitoes. Environmental temperature is also the key factor for microfilariae development in mosquito vectors (e.g., L3 require 16-20 days at $22{ }^{\circ} \mathrm{C}$ ) [15]. Microfilariae do not develop to L3 at temperatures below $14{ }^{\circ} \mathrm{C}$ [27]. Several models showed that the expansion from Southern to Central and Northern Europe (but also in North America) is probable [27,192,271]. Both the heartworm predictive model (based on growing degree days) and the Dirofilaria development units show parts of Central Europe suitable for the establishment of these parasites [28]. In Central Europe, the possible transmission period for $D$. immitis is estimated to be three to four months, while 20 days 
to 2 months are estimated for some Northern European regions [15]. However, climatic changes might prolong these periods and allow for spreading to areas that are currently climatically unsuitable for these parasites and certain vectors.

\section{Factors Influencing the Prevalence and Distribution Dynamics of Angiostrongylus vasorum}

Angiostrongylus vasorum generally has patchy distribution with hyperendemic foci surrounded by low prevalence areas [272-274]. Its recent spread in various European territories calls for higher awareness by local veterinarians, as the absence of records in a given area may often be due to lack of information [8].

The emergence of $A$. vasorum in Central and Northern Europe is likely driven by a combination of factors, including wildlife movement to urban areas, increased dog movements, and possibly climatic changes.

Compared to $D$. immitis and $D$. repens, wildlife reservoirs are highly relevant for the distribution of $A$. vasorum. The prevalence of $A$. vasorum in wild canids in Europe, mainly red foxes and golden jackals, which act as natural reservoir of this parasite [4], is regionally high. Red foxes are ubiquitous, share recreational areas with dogs around urban contexts, and are usually subjected to reinfections that can lead to high worm burdens, as they do not reach effective immunity following $A$. vasorum infection $[4,241,275]$. As a consequence, they can act as a continuous source of environmental contamination, favoring the infection of gastropod intermediate hosts [276], and thereby the local establishment of the parasite [277].

Climatic changes may also play a role in the increase in the distribution of angiostrongylids, including $A$. vasorum, as their development from L1 to L3 inside snails may be positively influenced by the increase in environmental temperature, contrarily to crenosomatids [278-281]. Thus, it cannot be excluded that the current global warming may drive the further spread of $A$. vasorum. Water availability strongly affects the biology of intermediate $A$. vasorum hosts; thus, increased precipitations can act synergistically with increased temperatures in the spread of this metastrongyloid [274].

Lastly, dog relocation from endemic to non-endemic areas may cause the spread of parasites, including A. vasorum, and introduce the parasite into new areas [203,277,282-287].

Overall, the A. vasorum spread pattern seems to be multifocal and later coalescing, highlighting the need for larger and multicentral studies in order to support targeted interventions such as prophylactic anthelmintic treatments or testing [274].

\section{Conclusions}

Dirofilaria immitis, D. repens, and A. vasorum are spreading in Europe, and the relevance of these parasites is steadily increasing for dogs and veterinary practitioners in Central and Northern Europe. Housing conditions of dogs, increased animal movements, and climate change are important factors in the spread of these nematodes. Keeping dogs outside overnight seems to be a major factor for the establishment of D. immitis and D. repens. However, the establishment of invasive, diurnal, synanthropic, competent mosquito vectors such as Ae. albopictus may also influence the spread of these filarioid helminths. Although the reasons for the spread of $A$. vasorum are not definitely clarified, habitat sharing and increased chances of contact with red foxes seem to play a major role in the epidemiology of this parasite, which may also be influenced by increased temperature and precipitation, and dog relocations.

Research efforts focusing on these parasites vary by country, and cross-border studies are few. The available data are not easily comparable. Both Dirofilaria spp. and A. vasorum merit monitoring and further studies in Europe.

Author Contributions: H.-P.F. conceived and planned the manuscript; H.-P.F., S.M., and M.S.U. organized the review and drafted Sections 1, 4 and 5; A.B., D.D.-S., R.F., G.G., M.H., P.J., T.K., M.L., M.M., D.M., H.H.P., K.S., A.V.R., M.S., and C.S. reviewed the available literature and reports for each county, drafted Sections 2 and 3, and provided information for Sections 4 and 5; K.B.-L. analyzed the 
data for the figures. All authors participated in preparing the final version of the article and have approved its content. All authors have read and agreed to the published version of the manuscript.

Funding: This research received no external funding.

Data Availability Statement: No new data were generated for this review article.

Acknowledgments: Thanks to Open Access Funding by the organization of the XXXI SoIPa Conference/2021 ESDA Event.

Conflicts of Interest: P.J. has received lecture fees for invited lectures on emerging canine parasites in Finland. The other authors declare no conflict of interest.

\section{References}

1. Beugnet, F.; Chalvet-Monfray, K. Impact of climate change in the epidemiology of vector-borne diseases in domestic carnivores. Comp. Immunol. Microbiol. Infect. Dis. 2013, 36, 559-566. [CrossRef]

2. Caminade, C.; McIntyre, K.M.; Jones, A.E. Impact of recent and future climate change on vector-borne diseases. Ann. N. Y. Acad. Sci. 2019, 1436, 157-173. [CrossRef]

3. Wright, I.; Jongejan, F.; Marcondes, M.; Peregrine, A.; Baneth, G.; Bourdeau, P.; Bowman, D.D.; Breitschwerdt, E.B.; Capelli, G.; Cardoso, L.; et al. Parasites and vector-borne diseases disseminated by rehomed dogs. Parasites Vectors 2020, 13, 546. [CrossRef]

4. Gillis-Germitsch, N.; Tritten, L.; Hegglin, D.; Deplazes, P.; Schnyder, M. Conquering Switzerland: The emergence of Angiostrongylus vasorum in foxes over three decades and its rapid regional increase in prevalence contrast with the stable occurrence of lungworms. Parasitology 2020, 147, 1071-1079. [CrossRef]

5. Cardoso, L.; Schallig, H.; Persichetti, M.F.; Pennisi, M.G. New Epidemiological Aspects of Animal Leishmaniosis in Europe: The Role of Vertebrate Hosts Other Than Dogs. Pathogens 2021, 10, 307. [CrossRef]

6. Ogden, N.H.; Lindsay, L.R. Effects of Climate and Climate Change on Vectors and Vector-Borne Diseases: Ticks Are Different. Trends Parasitol. 2016, 32, 646-656. [CrossRef] [PubMed]

7. Traversa, D.; Morelli, S.; Di Cesare, A.; Diakou, A. Felid Cardiopulmonary Nematodes: Dilemmas Solved and New Questions Posed. Pathogens 2021, 10, 30. [CrossRef]

8. Elsheikha, H.M.; Holmes, S.A.; Wright, I.; Morgan, E.R.; Lacher, D.W. Recent advances in the epidemiology, clinical and diagnostic features, and control of canine cardio-pulmonary angiostrongylosis. Vet. Res. 2014, 45, 92. [CrossRef]

9. Capelli, G.; Genchi, C.; Baneth, G.; Bourdeau, P.; Brianti, E.; Cardoso, L.; Danesi, P.; Fuehrer, H.-P.; Giannelli, A.; Ionică, A.M.; et al. Recent advances on Dirofilaria repens in dogs and humans in Europe. Parasites Vectors 2018, 11, 1-21. [CrossRef]

10. Genchi, C.; Kramer, L.H. The prevalence of Dirofilaria immitis and D. repens in the Old World. Vet. Parasitol. 2020, $280,108995$. [CrossRef]

11. Alsarraf, M.; Levytska, V.; Mierzejewska, E.J.; Poliukhovych, V.; Rodo, A.; Alsarraf, M.; Kavalevich, D.; Dwużnik-Szarek, D.; Behnke, J.M.; Bajer, A. Emerging risk of Dirofilaria spp. infection in Northeastern Europe: High prevalence of Dirofilaria repens in sled dog kennels from the Baltic countries. Sci. Rep. 2021, 11, 1068. [CrossRef]

12. Deksne, G.; Davidson, R.K.; Buchmann, K.; Kärssin, A.; Kirjušina, M.; Gavarāne, I.; Miller, A.L.; Pálsdóttir, G.R.; Robertson, L.J.; Mørk, T.; et al. Parasites in the changing world-Ten timely examples from the Nordic-Baltic region. Parasite Epidemiol. Control 2020, 10, e00150. [CrossRef]

13. Deksne, G.; Jokelainen, P.; Oborina, V.; Lassen, B.; Akota, I.; Kutanovaite, O.; Zaleckas, L.; Cīrule, D.; Tupīts, A.; Pimanovs, V.; et al. The Zoonotic Parasite Dirofilaria repens Emerged in the Baltic Countries Estonia, Latvia, and Lithuania in 2008-2012 and Became Established and Endemic in a Decade. Vector Borne Zoonotic Dis. 2021, 21, 1-5. [CrossRef]

14. McCall, J.W.; Genchi, C.; Kramer, L.H.; Guerrero, J.; Venco, L. Heartworm disease in animals and humans. Adv. Parasitol. 2008, 66, 193-285. [CrossRef]

15. Simón, F.; Siles-Lucas, M.; Morchón, R.; González-Miguel, J.; Mellado, I.; Carretón, E.; Montoya-Alonso, J.A. Human and animal dirofilariasis: The emergence of a zoonotic mosaic. Clin. Microbiol. Rev. 2012, 25, 507-544. [CrossRef]

16. Johnson, C.A. Ursus americanus (Black Bear) a new host for Dirofilaria immitis. J. Parasitol. 1975, 61, 940. [CrossRef]

17. Venco, L.; Marchesotti, F.; Manzocchi, S. Feline heartworm disease: A 'Rubik's-cube-like' diagnostic and therapeutic challenge. J. Vet. Cardiol. 2015, 17 (Suppl. 1), S190-S201. [CrossRef] [PubMed]

18. Bajer, A.; Rodo, A.; Mierzejewska, E.J.; Tołkacz, K.; Welc-Falęciak, R. The prevalence of Dirofilaria repens in cats, healthy dogs and dogs with concurrent babesiosis in an expansion zone in central Europe. BMC Vet. Res. 2016, 12, 183. [CrossRef]

19. Alho, A.M.; Schnyder, M.; Schaper, R.; Meireles, J.; Belo, S.; Deplazes, P.; de Carvalho, L.M. Seroprevalence of circulating Angiostrongylus vasorum antigen and parasite-specific antibodies in dogs from Portugal. Parasitol. Res. 2016, 115, 2567-2572. [CrossRef]

20. Ames, M.K.; Atkins, C.E. Treatment of dogs with severe heartworm disease. Vet. Parasitol. 2020, 283, 109131. [CrossRef]

21. Dillon, A.R.; Blagburn, B.L.; Tillson, M.; Brawner, W.; Welles, B.; Johnson, C.; Cattley, R.; Rynders, P.; Barney, S. Heartwormassociated respiratory disease (HARD) induced by immature adult Dirofilaria immitis in cats. Parasites Vectors 2017, 10, 514. [CrossRef] [PubMed]

22. Theis, J.H. Public health aspects of dirofilariasis in the United States. Vet. Parasitol. 2005, 133, 157-180. [CrossRef] 
23. European Society of Dirofilariosis and Angiostrongylosis. ESDA Guidelines for Clinical Management of Subcutaneous Dirofilariosis in Dogs and Cats. 2017. Available online: www.esda.vet (accessed on 1 September 2020).

24. Tarello, W. Clinical Aspects of Dermatitis Associated with Dirofilaria repens in Pets: A Review of 100 Canine and 31 Feline Cases (1990-2010) and a Report of a New Clinic Case Imported from Italy to Dubai. J. Parasitol. Res. 2011, 2011, 578385. [CrossRef] [PubMed]

25. Rocconi, F.; Di Tommaso, M.; Traversa, D.; Palmieri, C.; Pampurini, F.; Boari, A. Allergic dermatitis by Dirofilaria repens in a dog: Clinical picture and treatment. Parasitol. Res. 2012, 111, 493-496. [CrossRef] [PubMed]

26. Potters, I.; Vanfraechem, G.; Bottieau, E. Dirofilaria repens Nematode Infection with Microfilaremia in Traveler Returning to Belgium from Senegal. Emerg. Infect. Dis. 2018, 24, 1761-1763. [CrossRef]

27. Genchi, C.; Rinaldi, L.; Cascone, C.; Mortarino, M.; Cringoli, G. Is heartworm disease really spreading in Europe? Vet. Parasitol. 2005, 133, 137-148. [CrossRef]

28. Genchi, C.; Mortarino, M.; Rinaldi, L.; Cringoli, G.; Traldi, G.; Genchi, M. Changing climate and changing vector-borne disease distribution: The example of Dirofilaria in Europe. Vet. Parasitol. 2011, 176, 295-299. [CrossRef]

29. Morgan, E.R.; Shaw, S.E.; Brennan, S.F.; de Waal, T.D.; Jones, B.R.; Mulcahy, G. Angiostrongylus vasorum: A real heartbreaker. Trends Parasitol. 2005, 21, 49-51. [CrossRef]

30. Guilhon, J.; Cens, B. Angiostrongilus vasorum (Baillet, 1866). Biological and morphological study. Ann. Parasitol. Hum. Comp. 1973, 48, 567-596. [CrossRef]

31. Mozzer, L.R.; Lima, W.S. Gallus gallus domesticus: Paratenic host of Angiostrongylus vasorum. Vet. Parasitol. 2015, 207, 81-84. [CrossRef]

32. Chapman, P.S.; Boag, A.K.; Guitian, J.; Boswood, A. Angiostrongylus vasorum infection in 23 dogs (1999-2002). J. Small Anim. Pract. 2004, 45, 435-440. [CrossRef]

33. Traversa, D.; Torbidone, A.; Malatesta, D.; Guglielmini, C. Occurrence of fatal canine Angiostrongylus vasorum infection in Italy. Vet. Parasitol. 2008, 152, 162-166. [CrossRef]

34. Traversa, D.; Di Cesare, A.; Meloni, S.; Di Regalbono, A.F.; Milillo, P.; Pampurini, F.; Venco, L. Canine angiostrongylosis in Italy: Occurrence of Angiostrongylus vasorum in dogs with compatible clinical pictures. Parasitol. Res. 2013, 112, 2473-2480. [CrossRef]

35. Holmes, S.A.; Paine, P.; Wright, I.; Morgan, E.R.; Elsheikha, H.M. Risk factors and predictors of angiostrongylosis in naturally infected dogs in the southeast of England. Companion Anim. 2020, 25, 233-240. [CrossRef]

36. Becskei, C.; Willesen, J.L.; Schnyder, M.; Wozniakiewicz, M.; Miroshnikova, N.; Mahabir, S.P. Field safety and efficacy of an orally administered combination of sarolaner, moxidectin and pyrantel (Simparica Trio ${ }^{\circledR}$ ) for the prevention of angiostrongylosis in dogs presented as veterinary patients. Parasites Vectors 2020, 13, 385. [CrossRef] [PubMed]

37. Gillis-Germitsch, N.; Manser, M.B.; Hilbe, M.; Schnyder, M. Meerkats (Suricata suricatta), a new definitive host of the canid nematode Angiostrongylus vasorum. Int. J. Parasitol. Parasites Wildl. 2017, 6, 349-353. [CrossRef]

38. Bagardi, M.; Rabbogliatti, V.; Bassi, J.; Gioeni, D.; Oltolina, M.; Villa, L. Angiostrongylus vasorum in a Red Panda (Ailurus fulgens): Clinical Diagnostic Trial and Treatment Protocol. Acta Parasitol. 2021, 66, 282-286. [CrossRef]

39. Bertelsen, M.F.; Meyland-Smith, F.; Willesen, J.L.; Jefferies, R.; Morgan, E.R.; Monrad, J. Diversity and prevalence of metastrongyloid nematodes infecting the red panda (Ailurus fulgens) in European zoos. Vet. Parasitol. 2010, 172, 299-304. [CrossRef] [PubMed]

40. Lemming, L.; Jørgensen, A.C.; Nielsen, L.B.; Nielsen, S.T.; Mejer, H.; Chriél, M.; Petersen, H.H. Cardiopulmonary nematodes of wild carnivores from Denmark: Do they serve as reservoir hosts for infections in domestic animals? Int. J. Parasitol. Parasites Wildl. 2020, 13, 90-97. [CrossRef]

41. Gueldner, E.K.; Schuppisser, C.; Borel, N.; Hilbe, M.; Schnyder, M. First case of a natural infection in a domestic cat (Felis catus) with the canid heart worm Angiostrongylus vasorum. Vet. Parasitol. Reg. Stud. Rep. 2019, 18, 100342. [CrossRef] [PubMed]

42. Di Cesare, A.; Morelli, S.; Colombo, M.; Simonato, G.; Veronesi, F.; Marcer, F.; Diakou, A.; D'Angelosante, R.; Pantchev, N.; Psaralexi, E.; et al. Is Angiostrongylosis a Realistic Threat for Domestic Cats? Front. Vet. Sci. 2020, 7, 195. [CrossRef] [PubMed]

43. Diakou, A.; Dimzas, D.; Astaras, C.; Savvas, I.; di Cesare, A.; Morelli, S.; Neofitos, K.; Migli, D.; Traversa, D. Clinical investigations and treatment outcome in a European wildcat (Felis silvestris silvestris) infected by cardio-pulmonary nematodes. Vet. Parasitol. Reg. Stud. Rep. 2020, 19, 100357. [CrossRef] [PubMed]

44. Segovia, J.M.; Torres, J.; Miquel, J. Helminth parasites of the red fox [Vulpes vulpes L., 1758] in the Iberian Peninsula: An ecological study. Acta Parasitol. 2004, 49, 67-79.

45. Segovia, J.M.; Torres, J.; Miquel, J.; Llaneza, L.; Feliu, C. Helminths in the wolf, Canis lupus, from north-western Spain. J. Helminthol. 2001, 75, 183-192.

46. Benda, T.; Csivincsik, Á.; Nemes, C.; Turbók, J.; Zsolnai, A.; Simonyai, E.; Majoros, G.; Nagy, G. Lethal Angiostrongylus vasorum infection in a Hungarian dog. Acta Parasitol. 2017, 62, 221-224. [CrossRef] [PubMed]

47. Deak, G.; Gillis-Germitsch, N.; Ionică, A.M.; Mara, A.; Păstrav, I.R.; Cazan, C.D.; Ioniță, M.; Mitrea, I.L.; Răileanu, C.; Bărburaș, D.; et al. The first seroepidemiological survey for Angiostrongylus vasorum in domestic dogs from Romania. Parasites Vectors 2019, 12, 224. [CrossRef]

48. Čabanová, V.; Miterpáková, M.; Druga, M.; Hurníková, Z.; Valentová, D. GIS-based environmental analysis of fox and canine lungworm distribution: An epidemiological study of Angiostrongylus vasorum and Crenosoma vulpis in red foxes from Slovakia. Parasitol. Res. 2018, 117, 521-530. [CrossRef] 
49. Takács, A.; Szabó, L.; Juhász, L.; Lanszki, J.; Takács, P.; Heltai, M. Data on the parasitological status of golden jackal (Canis aureus L., 1758) in Hungary. Acta Vet. Hung. 2014, 62, 33-41. [CrossRef]

50. Tolnai, Z.; Széll, Z.; Sréter, T. Environmental determinants of the spatial distribution of Angiostrongylus vasorum, Crenosoma vulpis and Eucoleus aerophilus in Hungary. Vet. Parasitol. 2015, 207, 355-358. [CrossRef]

51. Fuehrer, H.-P.; Morelli, S.; Bleicher, J.; Brauchart, T.; Edler, M.; Eisschiel, N.; Hering, T.; Lercher, S.; Mohab, K.; Reinelt, S.; et al Detection of Crenosoma spp., Angiostrongylus vasorum and Aelurostrongylus abstrusus in Gastropods in Eastern Austria. Pathogens 2020, 9, 1046. [CrossRef]

52. Grandi, G.; Lind, E.O.; Schaper, R.; Ågren, E.; Schnyder, M. Canine angiostrongylosis in Sweden: A nationwide seroepidemiological survey by enzyme-linked immunosorbent assays and a summary of five-year diagnostic activity (2011-2015). Acta Vet. Scand. 2017, 59, 85. [CrossRef]

53. Lempereur, L.; Martinelle, L.; Marechal, F.; Bayrou, C.; Dalemans, A.C.; Schnyder, M.; Losson, B. Prevalence of Angiostrongylus vasorum in southern Belgium, a coprological and serological survey. Parasites Vectors 2016, 9, 533. [CrossRef]

54. Tiškina, V.; Lindqvist, E.-L.; Blomqvist, A.-C.; Orav, M.; Stensvold, C.R.; Jokelainen, P. Autochthonous Angiostrongylus vasorum in Finland. Vet. Rec. Open 2019, 6, e000314. [CrossRef] [PubMed]

55. Mikola, N.; Oborina, V.; Jokelainen, P. Knowledge About Emerging Zoonotic Vector-Borne Parasites Dirofilaria immitis and Dirofilaria repens in Finland: Questionnaire Survey to Medical Doctors and Veterinarians. Vector Borne Zoonotic Dis. 2020, $20,27-32$. [CrossRef] [PubMed]

56. Tiškina, V.; Jokelainen, P. Vector-borne parasitic infections in dogs in the Baltic and Nordic countries: A questionnaire study to veterinarians on canine babesiosis and infections with Dirofilaria immitis and Dirofilaria repens. Vet. Parasitol. 2017, $244,7-11$. [CrossRef]

57. Hinaidy, H.K.; Bacowsky, H.; Hinterdorfer, F. Einschleppung der Hunde-Filarien Dirofilaria immitis und Dipetalonema reconditum nach Osterreich. J. Vet. Med. Ser. B 1987, 34, 326-332. [CrossRef]

58. Löwenstein, M.; Meissel, H.; Koller, J. Dirofilaria immitis in dogs in Austria. Wiener Tierarztliche Monatsschrift 1988, 75, 420-424.

59. Kleiter, M.; Luckschander, N.; Willmann, M. Kutane Dirofilariose (Dirofilaria repens) bei zwei nach Österreich importierten Hunden. Kleintierpraxis 2001, 46, 283-288.

60. Leschnik, M.; Löwenstein, M.; Edelhofer, R.; Kirtz, G. Imported non-endemic, arthropod-borne and parasitic infectious diseases in Austrian dogs. Wiener Klinische Wochenschrift 2008, 120, 59-62. [CrossRef]

61. Duscher, G.G.; Feiler, A.; Wille-Piazzai, W.; Bakonyi, T.; Leschnik, M.; Miterpáková, M.; Kolodziejek, J.; Nowotny, N.; Joachim, A. Nachweis von Dirofilarien in österreichischen Hunden. Berliner und Munchener Tierarztliche Wochenschrift 2009, 122, $199-203$.

62. Fuehrer, H.-P.; Auer, H.; Leschnik, M.; Silbermayr, K.; Duscher, G.G.; Joachim, A. Dirofilaria in Humans, Dogs, and Vectors in Austria (1978-2014)-From Imported Pathogens to the Endemicity of Dirofilaria repens. PLoS Negl. Trop. Dis. 2016, 10, e0004547. [CrossRef]

63. Sonnberger, K.; Duscher, G.G.; Fuehrer, H.-P.; Leschnik, M. Current trends in canine dirofilariosis in Austria-do we face a pre-endemic status? Parasitol. Res. 2020, 119, 1001-1009. [CrossRef]

64. Sonnberger, K.; Fuehrer, H.-P.; Sonnberger, B.W.; Leschnik, M.; Fuehrer, H.-P.; Sonnberger, B.W.; Leschnik, M. The Incidence of Dirofilaria immitis in Shelter Dogs and Mosquitoes in Austria. Pathogens 2021, 10, 550. [CrossRef] [PubMed]

65. Sonnberger, B.W.; Graf, B.; Straubinger, R.K.; Rackl, D.; Obwaller, A.G.; Peschke, R.; Barogh, B.S.; Joachim, A.; Fuehrer, H.-P. Vector-borne pathogens in clinically healthy military working dogs in eastern Austria. Parasitol. Int. 2021, 84, 102410. [CrossRef]

66. Kulmer, L.M.; Unterköfler, M.S.; Fuehrer, H.-P.; Janovska, V.; Pagac, M.; Svoboda, M.; Venco, L.; Leschnik, M. First Autochthonous Infection of a Cat with Dirofilaria immitis in Austria. Pathogens 2021, 10, 1104. [CrossRef] [PubMed]

67. Hodžić, A.; Mrowietz, N.; Cézanne, R.; Bruckschwaiger, P.; Punz, S.; Habler, V.E.; Tomsik, V.; Lazar, J.; Duscher, G.G.; Glawischnig, W.; et al. Occurrence and diversity of arthropod-transmitted pathogens in red foxes (Vulpes vulpes) in western Austria, and possible vertical (transplacental) transmission of Hepatozoon canis. Parasitology 2018, 145, 335-344. [CrossRef] [PubMed]

68. Bardach, H.; Heimbucher, J.; Raff, M. Sulkutane Dirofilaria (Nochtiella) repens. Infektion Beim Menschen. Erste Fallbeschreibung In Oesterreich Und Uebersicht Der Literatur. Wiener Klinische Wochenschrift 1981, 93, 123-127.

69. Auer, H.; Susani, M. Der erste autochthone Fall einer subkutanen Dirofilariose in Osterreich. Wiener Klinische Wochenschrift 2008, 120, 104-106. [CrossRef]

70. Riebenbauer, K.; Weber, P.B.; Walochnik, J.; Karlhofer, F.; Winkler, S.; Dorfer, S.; Auer, H.; Valencak, J.; Laimer, M.; Handisurya, A. Human dirofilariosis in Austria: The past, the present, the future. Parasites Vectors 2021, 14, 1-10. [CrossRef]

71. Haim, A.; Kitchen, M.; Auer, H.; Rettenbacher, T.; Schmuth, M. A case of human Dirofilaria repens infection, causing an asymptomatic subcutaneous nodule. Parasitol. Res. 2020, 119, 1703-1705. [CrossRef]

72. Silbermayr, K.; Eigner, B.; Joachim, A.; Duscher, G.G.; Seidel, B.; Allerberger, F.; Indra, A.; Hufnagl, P.; Fuehrer, H.-P. Autochthonous Dirofilaria repens in Austria. Parasites Vectors 2014, 7, 1-3. [CrossRef]

73. Übleis, S.S.; Cuk, C.; Nawratil, M.; Butter, J.; Schoener, E.; Obwaller, A.G.; Zechmeister, T.; Duscher, G.G.; Rubel, F.; Lebl, K.; et al. Xenomonitoring of Mosquitoes (Diptera: Culicidae) for the Presence of Filarioid Helminths in Eastern Austria. Can. J. Infect. Dis. Med. Microbiol. 2018, 2018, 9754695. [CrossRef]

74. Schoener, E.; Zittra, C.; Weiss, S.; Walder, G.; Barogh, B.S.; Weiler, S.; Fuehrer, H.-P. Monitoring of alien mosquitoes of the genus Aedes (Diptera: Culicidae) in Austria. Parasitol. Res. 2019, 118, 1633-1638. [CrossRef] 
75. Fuehrer, H.-P.; Schoener, E.; Weiler, S.; Barogh, B.S.; Zittra, C.; Walder, G. Monitoring of alien mosquitoes in Western Austria (Tyrol, Austria, 2018). PLoS Negl. Trop. Dis. 2020, 14, e0008433. [CrossRef]

76. Bakran-Lebl, K.; Zittra, C.; Harl, J.; Barogh, B.S.; Grätzl, A.; Ebmer, D.; Schaffner, F.; Fuehrer, H.-P. Arrival of the Asian tiger mosquito, Aedes albopictus (Skuse, 1895) in Vienna, Austria, and initial monitoring activities. Transbound. Emerg. Dis. 2021. [CrossRef]

77. Svobodova, V.; Misonova, P. The potential risk of Dirofilaria immitis becoming established in the Czech Republic by imported dogs. Vet. Parasitol. 2005, 128, 137-140. [CrossRef]

78. Svobodová, Z.; Svobodová, V.; Genchi, C.; Forejtek, P. The first report of authochthonous dirofilariosis in dogs in the Czech Republic. Helminthologia 2006, 43, 242-245. [CrossRef]

79. Miterpáková, M.; Hurníková, Z.; Valentová, D.; Borková, L.; Zuzana, H.; Lenka, B. Different epidemiological pattern of canine dirofilariosis in two neighboring countries in Cent0ral Europe-the Czech Republic and Slovakia. Parasitol. Res. 2021, 120, 547-552. [CrossRef]

80. Rudolf, I.; Šebesta, O.; Mendel, J.; Betášová, L.; Bocková, E.; Jedličková, P.; Venclíková, K.; Blažejová, H.; Šikutová, S.; Hubálek, Z. Zoonotic Dirofilaria repens (Nematoda: Filarioidea) in Aedes vexans mosquitoes, Czech Republic. Parasitol. Res. 2014, 113, 4663-4667. [CrossRef] [PubMed]

81. Matějů, J.; Chanová, M.; Modrý, D.; Mitková, B.; Hrazdilová, K.; Žampachová, V.; Kolářová, L. Dirofilaria repens: Emergence of autochthonous human infections in the Czech Republic (case reports). BMC Infect. Dis. 2016, 16, 171. [CrossRef] [PubMed]

82. Gebauer, J.; Ondruš, J.; Kulich, P.; Novotný, L.; Sałamatin, R.; Husa, P.; Novobilský, A. The first case of periorbital human dirofilariasis in the Czech Republic. Parasitol. Res. 2021, 120, 739-742. [CrossRef]

83. Leuterer, G.; Gothe, R. Die Herzwurmkrankheit des Hundes: Erregerbiologie und-okologie, Pathogenese, Klinik, Diagnose, Therapie und Prophylaxe. Canine heartworm disease: Biology and ecology of the causative agent, pathogenesis, clinical signs, diagnosis, therapy and prophylaxis. Kleintierpraxis 1993, 38, 633-646.

84. Glaser, B.; Gothe, R. Importierte arthropodenübertragene Parasiten und parasitische Arthropoden beim Hund. Erregerspektrum und epidemiologische Analyse der 1995/96 diagnostizierten Fälle. Tierarztl. Prax. Ausg. K Kleintiere. Heimtiere. 1998, 26, 40-46. [PubMed]

85. Schrey, C.F. Epidemiologische Fallanalyse und Klinik der Kardiovaskulären Dirofilariose (Herzwurmerkrankung) bei Hunden in Deutschland; Free University of Berlin: Berlin, Germany, 1996.

86. Wohlsein, P.; Vilafranca, M.; Brandes, B. Leishmaniose und Filariose bei einem Hund. Kleintierpraxis 1996, 25, 367-374.

87. Zahler, M.; Glaser, B.; Gothe, R. Imported parasites in dogs: Dirofilaria repens and Dipetalonema reconditum. Tierarztliche Praxis 1997, 25, 388-392. [PubMed]

88. Hermosilla, C.; Pantchev, N.; Dyachenko, V.; Gutmann, M.; Bauer, C. First autochthonous case of canine ocular Dirofilaria repens infection in Germany. Vet. Rec. 2006, 158, 134-135. [CrossRef]

89. Sassnau, R.; Dyachenko, V.; Pantchev, N.; Stockel, F.; Dittmar, K.; Daugschies, A. Dirofilaria-repens-Befall in einem SchlittenhundeRudel im Land Brandenburg. Diagnose und Therapie der kaninen kutanen Dirofilariose. Tierarztl. Prax. Ausg. K Kleintiere. Heimtiere. 2009, 37, 95.

90. Pantchev, N.; Norden, N.; Lorentzen, L.; Rossi, M.; Rossi, U.; Brand, B.; Dyachenko, V. Current surveys on the prevalence and distribution of Dirofilaria spp. in dogs in Germany. Parasitol. Res. 2009, 105 (Suppl. 1), S63-S74. [CrossRef]

91. Hirsch, M.; Pantchev, N. Vorkommenshäufigkeit der Reisekrankheiten Leishmaniose, Ehrlichiose, Babesiose und Dirofilariose bei in Deutschland lebenden Hunden. Kleintierpraxis 2008, 12, 154-165.

92. Pantchev, N.; Etzold, M.; Daugschies, A.; Dyachenko, V. Diagnosis of imported canine filarial infections in Germany 2008-2010. Parasitol. Res. 2011, 109 (Suppl. 1), S61-S76. [CrossRef]

93. Röhrig, E.; Hamel, D.; Pfister, K. Retrospective evaluation of laboratory data on canine vector-borne infections from the years 2004-2008. Berliner und Munchener Tierarztliche Wochenschrift 2011, 124, 411-418.

94. Vrhovec, M.G.; Pantchev, N.; Failing, K.; Bauer, C.; Travers-Martin, N.; Zahner, H. Retrospective Analysis of Canine Vector-borne Diseases (CVBD) in Germany with Emphasis on the Endemicity and Risk Factors of Leishmaniosis. Parasitol. Res. 2017, 116, 131-144. [CrossRef]

95. Menn, B.; Lorentz, S.; Naucke, T.J. Imported and travelling dogs as carriers of canine vector-borne pathogens in Germany. Parasites Vectors 2010, 3, 34. [CrossRef]

96. Hamel, D.; Röhrig, E.; Pfister, K. Canine vector-borne disease in travelled dogs in Germany-a retrospective evaluation of laboratory data from the years 2004-2008. Vet. Parasitol. 2011, 181, 31-36. [CrossRef]

97. Czajka, C.; Becker, N.; Poppert, S.; Jöst, H.; Schmidt-Chanasit, J.; Krüger, A. Molecular detection of Setaria tundra (Nematoda: Filarioidea) and an unidentified filarial species in mosquitoes in Germany. Parasites Vectors 2012, 5, 14. [CrossRef]

98. Czajka, C.; Becker, N.; Jöst, H.; Poppert, S.; Schmidt-Chanasit, J.; Krüger, A.; Tannich, E. Stable transmission of Dirofilaria repens nematodes, northern Germany. Emerg. Infect. Dis. 2014, 20, 328-331. [CrossRef] [PubMed]

99. Heym, E.C.; Kampen, H.; Krone, O.; Schäfer, M.; Werner, D. Molecular detection of vector-borne pathogens from mosquitoes collected in two zoological gardens in Germany. Parasitol. Res. 2019, 118, 2097-2105. [CrossRef] [PubMed]

100. Kronefeld, M.; Kampen, H.; Sassnau, R.; Werner, D. Molecular detection of Dirofilaria immitis, Dirofilaria repens and Setaria tundra in mosquitoes from Germany. Parasites Vectors 2014, 7, 30. [CrossRef] 
101. Sassnau, R.; Daugschies, A.; Lendner, M.; Genchi, C. Climate suitability for the transmission of Dirofilaria immitis and D. repens in Germany. Vet. Parasitol. 2014, 205, 239-245. [CrossRef] [PubMed]

102. Sassnau, R.; Czajka, C.; Kronefeld, M.; Werner, D.; Genchi, C.; Tannich, E.; Kampen, H. Dirofilaria repens and Dirofilaria immitis DNA findings in mosquitoes in Germany: Temperature data allow autochthonous extrinsic development. Parasitol. Res. 2014, 113, 3057-3061. [CrossRef]

103. Sassnau, R.; Genchi, C. Qualitative risk assessment for the endemisation of Dirofilaria repens in the state of Brandenburg (Germany) based on temperature-dependent vector competence. Parasitol. Res. 2013, 112, 2647-2652. [CrossRef]

104. Sassnau, R.; Kohn, M.; Demeler, J.; Kohn, B.; Müller, E.; Krücken, J.; von Samson-Himmelstjerna, G. Is Dirofilaria repens endemic in the Havelland district in Brandenburg, Germany? Vector Borne Zoonotic Dis. 2013, 13, 888-891. [CrossRef]

105. Härtwig, V.; Daugschies, A.; Dyachenko, V. Dirofilaria-repens-Befall bei einem Hund aus Mitteldeutschland ohne Reisevorbericht. Ein Fallbericht. Tierarztl. Prax. Ausg. K Kleintiere. Heimtiere. 2015, 43, 181-187. [CrossRef]

106. Tappe, D.; Plauth, M.; Bauer, T.; Muntau, B.; Dießel, L.; Tannich, E.; Herrmann-Trost, P. A case of autochthonous human Dirofilaria infection, Germany, March 2014. Euro Surveill. 2014, 19, 2-4. [CrossRef] [PubMed]

107. Härtwig, V.; Schulze, C.; Barutzki, D.; Schaper, R.; Daugschies, A.; Dyachenko, V. Detection of Angiostrongylus vasorum in Red Foxes (Vulpes vulpes) from Brandenburg, Germany. Parasitol. Res. 2015, 114 (Suppl. 1), S185-S192. [CrossRef]

108. Liesner, J.M.; Krücken, J.; Schaper, R.; Pachnicke, S.; Kohn, B.; Müller, E.; Schulze, C.; Samson-Himmelstjerna, G. von. Vector-borne pathogens in dogs and red foxes from the federal state of Brandenburg, Germany. Vet. Parasitol. 2016, 224, 44-51. [CrossRef] [PubMed]

109. Schäfer, I.; Volkmann, M.; Beelitz, P.; Merle, R.; Müller, E.; Kohn, B. Retrospective evaluation of vector-borne infections in dogs imported from the Mediterranean region and southeastern Europe (2007-2015). Parasites Vectors 2019, 12, 30. [CrossRef]

110. Schäfer, I.; Volkmann, M.; Beelitz, P.; Merle, R.; Müller, E.; Kohn, B. Retrospective analysis of vector-borne infections in dogs after travelling to endemic areas (2007-2018). Vet. Parasitol. X 2019, 2, 100015. [CrossRef]

111. Schäfer, I.; Kohn, B.; Volkmann, M.; Müller, E. Retrospective evaluation of vector-borne pathogens in cats living in Germany (2012-2020). Parasites Vectors 2021, 14, 123. [CrossRef] [PubMed]

112. Kotlán, S. On a new case of human filarioidosis in Hungary. Acta Vet. Acad. Sci. Hung. 1951, 1, 69-79.

113. Szénási, Z.; Kovács, A.H.; Pampiglione, S.; Fioravanti, M.L.; Kucsera, I.; Tánczos, B.; Tiszlavicz, L. Human dirofilariosis in Hungary: An emerging zoonosis in central Europe. Wiener Klinische Wochenschrift 2008, 120, 96-102. [CrossRef] [PubMed]

114. Fodor, E.; Fok, É.; Maka, E.; Lukáts, O.; Tóth, J. Recently recognized cases of ophthalmofilariasis in Hungary. Eur. J. Ophthalmol. 2009, 19, 675-678. [CrossRef] [PubMed]

115. Dóczi, I.; Bereczki, L.; Gyetvai, T.; Fejes, I.; Skribek, Á.; Szabó, Á.; Berkes, S.; Tiszlavicz, L.; Bartha, N.; Bende, B.; et al. Description of five dirofilariasis cases in South Hungary and review epidemiology of this disease for the country. Wiener Klinische Wochenschrift 2015, 127, 696-702. [CrossRef]

116. Fok, É.; Szabó, Z.; Farkas, R. Dirofilaria repens első hazai diagnosztizálása kutyában sebészeti beavatkozás sorá. Kisállatorvoslás 1998, 4, 218-219.

117. Széll, Z.; Sréter, T.; Csikós, K.; Kátai, Z.; Dobos-Kovács, M.; Vetési, F. Dirofilaria repens fertőzöttség kutyákban. Magyar Állatorvosok Lapja 1999, 121, 100-104.

118. Fok, É.; Kiss, G.; Majoros, G.; Jacsó, O.; Farkas, R.; Gyurkovszky, M. Preliminary results of an epidemiological survey on dirofilariosis of dogs and cats in Hungary. Mappe Parassitologiche 2007, 8, 195-196.

119. Jacsó, O. Distribution and Veterinary Importance of Dirofilaria Species in Hungary, and Treatment Experience; Szent István University: Budapest, Hungary, 2014.

120. Farkas, R.; Mag, V.; Gyurkovszky, M.; Takács, N.; Vörös, K.; Solymosi, N. The current situation of canine dirofilariosis in Hungary. Parasitol. Res. 2020, 119, 129-135. [CrossRef]

121. Kemenesi, G.; Kurucz, K.; Kepner, A.; Dallos, B.; Oldal, M.; Herczeg, R.; Vajdovics, P.; Bányai, K.; Jakab, F. Circulation of Dirofilaria repens, Setaria tundra, and Onchocercidae species in Hungary during the period 2011-2013. Vet. Parasitol. 2015, $214,108-113$. [CrossRef]

122. Boros, G.; Janisch, M.; Sebesyén, G. Dirofilaria immitis fertőzöttség kutyában. Magyar Állatorvosok Lapja 1982, 122, 313-316.

123. Vörös, K.; Kiss, G.; Baska, F.; Bagdi, N.; Széll, Z. Heartworm disease in dogs. Review article and case report. Magyar Állatorvosok Lapja 2000, 122, 707-716.

124. Jacsó, O.; Mándoki, M.; Majoros, G.; Pétsch, M.; Mortarino, M.; Genchi, C.; Fok, É. First autochthonous Dirofilaria immitis (Leidy, 1856) infection in a dog in Hungary. Helminthologia 2009, 46, 159-161. [CrossRef]

125. Farkas, R.; Gyurkovszky, M.; Lukács, Z.; Aladics, B.; Solymosi, N. Seroprevalence of some vector-borne infections of dogs in Hungary. Vector Borne Zoonotic Dis. 2014, 14, 256-260. [CrossRef]

126. Túri, Á.; Hetyey, C. Dirofilaria immitis elso magyarországi kimutatása a tüdo-artériában echokardiográfiás vizsgálattal. Magyar Állatorvosok Lapja 2014, 136, 231-233.

127. Bacsadi, Á.; Papp, A.; Szeredi, L.; Tóth, G.; Nemes, C.; Imre, V.; Tolnai, Z.; Széll, Z.; Sréter, T. Retrospective study on the distribution of Dirofilaria immitis in dogs in Hungary. Vet. Parasitol. 2016, 220, 83-86. [CrossRef]

128. Vörös, K.; Becker, Z.; Arany-Tóth, A.; Gyurkovszky, M.; Farkas, R. Okkult Dirofilaria immitis szívférgesség kutyában: Esetismertetés és irodalmi áttekintés. Magyar Állatorvosok Lapja 2017, 139, 675-685. 
129. Tolnai, Z.; Széll, Z.; Sproch, T.; Szeredi, L.; Sréter, T. Dirofilaria immitis: An emerging parasite in dogs, red foxes and golden jackals in hungary. Vet. Parasitol. 2014, 203, 339-342. [CrossRef] [PubMed]

130. Molnár, V.; Pazár, P.; Rigó, D.; Máthé, D.; Fok, T.; Glávits, R.; Vajdovich, P.; Jacsó, O.; Balogh, L.; Sós, E. Autochthonous Dirofilaria immitis infection in a ferret with aberrant larval migration in Europe. J. Small Anim. Pract. 2010, 51, 393-396. [CrossRef]

131. Sréter, T.; Széll, Z.; Marucci, G.; Pozio, E.; Varga, I. Extraintestinal nematode infections of red foxes (Vulpes vulpes) in Hungary. Vet. Parasitol. 2003, 115, 329-334. [CrossRef]

132. Ries, C.; Schaffner, F. Krankheitsübertragende Stechmücken (Culicidae) in Luxemburg und Europa. Luxembourg, 7 November. 2019. Available online: https:/ / mosquitoes.lu/posters/Poster $\% 20$ A0\%20Pest $\% 20$ mosquitoes $\% 20$ in $\% 20$ LU\%20and $\% 20$ Eruope $\%$ 202019\%20with\%20crop\%20marks\%20DE.pdf (accessed on 30 August 2021).

133. Demiaszkiewicz, A.W.; Polańczyk, G.; Pyziel, A.M.; Kuligowska, I.; Lachowicz, J. Pierwsze ogniska dirofilariozy psow wywolanej przez Dirofilaria repens Railliet et Henry, 1911 w centralnej Polsce. Ann. Parasitol. 2009, 55, 367-370.

134. Demiaszkiewicz, A.W.; Polańczyk, G. Pierwszy w Polsce przypadek inwazji Dirofilaria repens u psa. Magazyn Weterynaryjny 2010, 19, 254-256.

135. Sapierzyński, R.; Fabisiak, M.; Sałamaszyńska, A. Several cases of dirofilariosis accidentally diagnosed in dogs from Poland, including two PCR positive Dirofilaria repens cases. Pol. J. Vet. Sci. 2010, 13, 545-547.

136. Masny, A.; Lewin, T.; Sałamatin, R.V.; Gołąb, E. Autochthonous canine Dirofilaria repens in the vicinity of Warsaw. Pol. J. Vet. Sci. 2011, 14, 659-661. [CrossRef]

137. Demiaszkiewicz, A.W.; Pyziel, A.M. Przypadek dirofilariozy powiekowej u psa w Polsce. Magazyn Weterynaryjny 2012, 21, 342-344.

138. Demiaszkiewicz, A.W.; Karamon, J.; Jasik, A. Przypadek wykrycia nicienia Dirofilaria repens w jądrze psa. Medycyna Weterynaryjna 2013, 69, 124-127.

139. Demiaszkiewicz, A.W.; Polańczyk, G.; Osińska, B.; Pyziel, A.M.; Kuligowska, I.; Lachowicz, J.; Sikorski, A. Prevalence and distribution of Dirofilaria repens Railliet et Henry, 1911 in dogs in Poland. Pol. J. Vet. Sci. 2014, 17, 515-517. [CrossRef] [PubMed]

140. Bajer, A.; Mierzejewska, E.J.; Rodo, A.; Bednarska, M.; Kowalec, M.; Welc-Falęciak, R. The risk of vector-borne infections in sled dogs associated with existing and new endemic areas in Poland: Part 1: A population study on sled dogs during the racing season. Vet. Parasitol. 2014, 202, 276-286. [CrossRef]

141. Demiaszkiewicz, A.W.; Polańczyk, G.; Osińska, B.; Pyziel, A.M.; Kuligowska, I.; Lachowicz, J.; Sikorski, A. The prevalence and distribution of Dirofilaria repens in dogs in the Mazovian Province of central-eastern Poland. Ann. Agric. Environ. Med. 2014, 21, 701-704. [CrossRef] [PubMed]

142. Adaszek, L.; Janecki, R.; Lachowicz, K.; Teodorowski, O.; Winiarczyk, S. Czy zarażenia Dirofilaria immitis stanowią zagrożenie dla psów w Polsce? Magazyn Weterynaryjny 2021, 4, 1-2.

143. Masny, A.; Gołąb, E.; Cielecka, D.; Sałamatin, R.V.; Cielecka, D. Vector-borne helminths of dogs and humans focus on central and eastern parts of Europe. Parasites Vectors 2013, 6, 38. [CrossRef]

144. Cielecka, D.; Szymanska, K.; Sałamatin, R.V.; Tomaszewska, A. Przypadek inwazji Dirofilaria repens (Leidy, 1856)(Nematoda: Filarioidea: Onchocercidae) u pacjenta w Warszawie. Wiadomości Parazytologiczne 2007, 53, 165.

145. Żarnowska-Prymek, H.; Cielecka, D.; Sałamatin, R.V. Dirofilarioza-Dirofilaria repens, po raz pierwszy opisana u polskich pacjentów. Przegląd Epidemiologiczny 2008, 62, 547-551.

146. Wesołowska, M.; Szaliński, M.; Zieliński, M.; Okulewicz, A.; Kisza, K.; Misiuk-Hojło, M. Dirofilaria repens-pierwszy przypadek dirofilariozy podspojówkowej w Polsce. Przewodnik Lekarza 2009, 12, 65.

147. Cielecka, D.; Żarnowska-Prymek, H.; Masny, A.; Sałamatin, R.V.; Wesołowska, M.; Gołąb, E.; Cielecka, D.; Żarnowska-Prymek, H.; Masny, A.; Sałamatin, R.V.; et al. Human dirofilariosis in Poland: The first cases of autochthonous infections with Dirofilaria repens. Ann. Agric. Environ. Med. 2012, 19, 445-450. [PubMed]

148. Demiaszkiewicz, A.W. Dirofilaria repens Railliet et Henry, 1911-a new parasite acclimatized in Poland. Ann. Parasitol. 2014, 60, 31-35. [PubMed]

149. Kłudkowska, M.; Pielok, Ł.; Frackowiak, K.; Masny, A.; Gołąb, E.; Paul, M. Dirofilaria repens infection as a cause of intensive peripheral microfilariemia in a Polish patient: Process description and cases review. Acta Parasitol. 2018, 63, 657-663. [CrossRef]

150. Borkowski, P.K.; Rymkiewicz, G.; Golebiewska, J.; Nestoros, N.; Romejko-Jarosinska, J.; Żarnowska-Prymek, H.; Masny, A.; Palucki, J.; Cielecka, D. The first case of human autochtonous subconjunctival dirofilariosis in Poland and MALT lymphoma as possible consequence of this parasitosis. Infect. Agents Cancer 2015, 10. [CrossRef]

151. Kołodziej, P.; Szostakowska, B.; Jarosz, B.; Pojasek, S.; Romak, M.; Kocki, J.; Bogucka-Kocka, A. The first case of elbow bursitis caused by Dirofilaria repens in humans. Open Forum Infect. Dis. 2019, 6. [CrossRef]

152. Świątalska, A.; Demiaszkiewicz, A.W. Pierwszy w Polsce rodzimy przypadek inwazji nicieni Dirofilaria immitis u psa. Życie Weterynaryjne 2012, 87, 685-686.

153. Krämer, F.; Schaper, R.; Schunack, B.; Połozowski, A.; Piekarska, J.; Szwedko, A.; Jodies, R.; Kowalska, D.; Schüpbach, D.; Pantchev, N. Serological detection of Anaplasma phagocytophilum, Borrelia burgdorferi sensu lato and Ehrlichia canis antibodies and Dirofilaria immitis antigen in a countrywide survey in dogs in Poland. Parasitol. Res. 2014, 113, 3229-3239. [CrossRef]

154. Svobodova, V.; Svobodova, Z.; Beladicova, V.; Valentová, D. First cases of canine dirofilariosis in Slovakia: A case report. Veterinární Medicína 2005, 50, 510. [CrossRef] 
155. Miterpáková, M.; Antolová, D.; Hurníková, Z.; Dubinský, P. Dirofilariosis in Slovakia-a new endemic area in Central Europe. Helminthologia 2008, 45, 20-23. [CrossRef]

156. Miterpáková, M.; Antolová, D.; Hurníková, Z.; Dubinský, P.; Pavlačka, A.; Németh, J. Dirofilaria infections in working dogs in Slovakia. J. Helminthol. 2010, 84, 173-176. [CrossRef]

157. Miterpáková, M.; Iglódyová, A.; Čabanová, V.; Stloukal, E.; Miklisová, D. Canine dirofilariosis endemic in Central Europe-10 years of epidemiological study in Slovakia. Parasitol. Res. 2016, 115, 2389-2395. [CrossRef]

158. Čabanová, V.; Pantchev, N.; Hurníková, Z.; Miterpáková, M. Recent study on canine vector-borne zoonoses in southern Slovakiaserologic survey. Acta Parasitol. 2015, 60, 749-758. [CrossRef]

159. Miterpáková, M.; Valentová, D.; Čabanová, V.; Berešíková, L'. Heartworm on the rise-new insights into Dirofilaria immitis epidemiology. Parasitol. Res. 2018, 117, 2347-2350. [CrossRef]

160. Miterpáková, M.; Zborovská, H.; Bielik, B.; Halán, M. The fatal case of an autochthonous heartworm disease in a dog from a non-endemic region of south-eastern Slovakia. Helminthologia 2020, 57, 154. [CrossRef]

161. Miterpáková, M.; Hurníková, Z.; Zaleśny, G.; Chovancová, B. Molecular evidence for the presence of Dirofilaria repens in beech marten (Martes foina) from Slovakia. Vet. Parasitol. 2013, 196, 544-546. [CrossRef] [PubMed]

162. Hurníková, Z.; Miterpáková, M.; Zaleśny, G. Epidemiological coherency of vulpine dirofilariosis in environmental conditions of Slovakia. Helminthologia 2015, 52, 11-16. [CrossRef]

163. Bocková, E.; Rudolf, I.; Kočišová, A.; Betášová, L.; Venclíková, K.; Mendel, J.; Hubálek, Z. Dirofilaria repens microfilariae in Aedes vexans mosquitoes in Slovakia. Parasitol. Res. 2013, 112, 3465-3470. [CrossRef]

164. Bocková, E.; Iglódyová, A.; Kočišová, A. Potential mosquito (Diptera: Culicidae) vector of Dirofilaria repens and Dirofilaria immitis in urban areas of Eastern Slovakia. Parasitol. Res. 2015, 114, 4487-4492. [CrossRef]

165. Čabanová, V.; Miterpáková, M.; Valentová, D.; Blažejová, H.; Rudolf, I.; Stloukal, E.; Hurníková, Z.; Dzidová, M. Urbanization impact on mosquito community and the transmission potential of filarial infection in central Europe. Parasites Vectors 2018, 11, 1-10. [CrossRef]

166. Vasilková, D.; Klisenbauer, D.; Juhas, T.; Moravec, F.; Uhlikova, M.; Hübner, J.; Konakova, G. Isolation of Dirofilaria repens in vitreoretinal findings. Ceskoslovenska Oftalmologie 1992, 48, 274-277. [PubMed]

167. Miterpáková, M.; Antolová, D.; Ondriska, F.; Gál, V. Human Dirofilaria repens infections diagnosed in Slovakia in the last 10 years (2007-2017). Wiener Klinische Wochenschrift 2017, 129, 634-641. [CrossRef] [PubMed]

168. Miterpáková, M.; Antolová, D.; Ondriska, F.; Boldiš, V. Filarial infections in human medicine and public health. Lekársky obzor 2021, 70, 512-513.

169. Brglez, J.; Senk, L. Dirofilaria immitis (Leidy, 1856) Railliet et Henry, 1911, pri psu: Zbornik Biotehniske Fakultete Univerze Edvardo Kardelja v Ljubljani. Veterinarstvo 1987, 24, 69-72.

170. Brglez, J.; Verbančič, Š. Podkožna oblika dirofilarioze pri lisici: Zbornik Biotehniske Fakultete Univerze Edvardo Kardelja v Ljubljani. Veterinarstvo 1988, 25, 53-56.

171. Logar, J.; Novsak, V.; Rakovec, S.; Stanisa, O. Subcutaneous infection caused by Dirofilaria repens imported to Slovenia. J. Infect. 2001, 42, 72-74. [CrossRef]

172. Otto, G.F. Geographical distribution, vectors, and life cycle of Dirofilaria immitis. J. Am. Vet. Med. Assoc. 1969, 154, $370-373$.

173. Savani, G. Distribuzione della microfilaria dei cani in Carpi, Novi, Concordia e dintorni. Scienze Mediche Colon 1933, 32, 357-364.

174. Vlach, G. La filariosi nei cani di Trieste e Provincia. Archicio Italionao di Scienze Mediche Colon 1936, 77, 418-445.

175. Depieds, R.; Remon, J. Etat actuel de l'endémicité à dirofilaria immitis chez le chien, dans la région d'hyères; apres les travaux récents de démoustiquation. Rev. Pathol. Gen. Physiol. Clin. 1955, 55, 824-826.

176. Ranque, J.; Clayette, J. La distribution géographique de la filariose canine dans la région provençale; ses rapports avec les anciennes zones d'endémie palustre. J. Med. Bord. 1951, 128, 258-259.

177. Kersten, W. Zum Vorkommen der Herzfilariose (Dirofilaria immitis) beim Hund. Dtsch Tieraerztl Wschr 1959, 66, $217-219$.

178. Thun, R. Die Herzwurmerkrankung des Hundes. Schweizer Archiv für Tierheilkunde 1975, 117, 99-111.

179. Arnold, P.; Deplazes, P.; Ruckstuhl, H.; Flückiger, M. Case report: Dirofilariasis in a dog. Schweizer Archiv für Tierheilkunde 1994, 136, 265-269.

180. Deplazes, P.; Guscetti, F.; Wunderlin, E.; Bucklar, H.; Skaggs, J.; Wolff, K. Endoparasitenbefall bei Findel- und Verzicht-Hunden in der Südschweiz. Schweizer Archiv für Tierheilkunde 1995, 137, 172-179.

181. Bucklar, H.; Scheu, U.; Mossi, R.; Deplazes, P. Breitet sich in der Südschweiz die Dirofilariose beim Hund aus? Schweizer Archiv für Tierheilkunde 1998, 140, 255-260.

182. Petruschke, G.; Rossi, L.; Genchi, C.; Pollono, F. Sulle dirofilariosi canine nel Canton Ticino e in aree confinanti del Nord Italia. Schweizer Archiv für Tierheilkunde 2001, 143, 141-147.

183. Suter, T.; Flacio, E.; Fariña, B.F.; Engeler, L.; Tonolla, M.; Müller, P. First report of the invasive mosquito species Aedes koreicus in the Swiss-Italian border region. Parasites Vectors 2015, 8, 402. [CrossRef]

184. Deplazes, P.; Staebler, S.; Gottstein, B. Reisemedizin parasitärer Erkrankungen des Hundes. Schweizer Archiv für Tierheilkunde 2006, 148, 447-461. [CrossRef]

185. Glaus, T.M.; Ivasovic, F.; Jörger, F.B.; Schreiber, N.; Baron Toaldo, M. Minimal invasive Extraktion von adulten Dirofilaria immitis bei einem Hund mit Kavalsyndrom. Schweizer Archiv für Tierheilkunde 2019, 161, 749-754. [CrossRef] 
186. Bausch, K.; Bosl, M.; Matter, M.; Gabrielli, S.; Neumayr, A. When you hear hoof beats ... consider zebras-A diagnostic challenge. Travel Med. Infect. Dis. 2017, 19, 73-74. [CrossRef]

187. Breitenbücher, A.; Gayer, R.; Giachino, D.; Mordasini, C. What is your diagnosis. Multiple pulmonary nodules. Respiration 1998, 65, 91-94. [CrossRef]

188. Hasler, S.; Grimm, F.; Thiel, M.A.; Müller, N.J.; Eberhard, R.; Bosch, M.M. Swiss patient with a subconjunctival Dirofilaria repens. Klin. Monbl. Augenheilkd. 2010, 227, 332-333. [CrossRef]

189. Jokelainen, P.; Mõtsküla, P.F.; Heikkinen, P.; Ülevaino, E.; Oksanen, A.; Lassen, B. Dirofilaria repens Microfilaremia in Three Dogs in Estonia. Vector Borne Zoonotic Dis. 2016, 16, 136-138. [CrossRef]

190. Sabūnas, V.; Radzijevskaja, J.; Sakalauskas, P.; Petkevičius, S.; Karvelienė, B.; Žiliukienè, J.; Lipatova, I.; Paulauskas, A. Dirofilaria repens in dogs and humans in Lithuania. Parasites Vectors 2019, 12, 177. [CrossRef]

191. Klintebjerg, K.; Petersen, E.; Pshenichnaya, N.Y.; Ermakova, L.A.; Nagorny, S.A.; Larsen, C.S. Periorbital Dirofilaria repens imported to Denmark: A human case report. IDCases 2015, 2, 25-26. [CrossRef]

192. Genchi, C.; Rinaldi, L.; Mortarino, M.; Genchi, M.; Cringoli, G. Climate and Dirofilaria infection in Europe. Vet. Parasitol. 2009, 163, 286-292. [CrossRef]

193. Pietikäinen, R.; Nordling, S.; Jokiranta, S.; Saari, S.; Heikkinen, P.; Gardiner, C.; Kerttula, A.-M.; Kantanen, T.; Nikanorova, A.; Laaksonen, S.; et al. Dirofilaria repens transmission in southeastern Finland. Parasites Vectors 2017, 10, 561. [CrossRef]

194. Oksanen, A. One Health. In Research on the Change in the North, Proceedings of the THULE SCIENCE DAYS 2015, Oulu, Finland, 27-28 October 2015; Highlights of the Thule Institute's Research Program 2012-2015; Kamula, R., Taskinen, P., Pongrácz, E., Rautio, A., Strand, K., Eds.; University of Oulu: Oulu, Finland, 2015; pp. 10-11. ISBN 978-952-62-1008-0.

195. Settnes, O.P.; Engebjerg, E. Human subcutaneous dirofilariasis caused by Dirofilaria repens. Report of a case in Norway and review of recent literature. APMIS 1991, 99, 364-370. [CrossRef]

196. Bredal, W.P.; Gjerde, B.; Eberhard, M.L.; Aleksandersen, M.; Wilhelmsen, D.K.; Mansfield, L.S. Adult Dirofilaria repens in a subcutaneous granuloma on the chest of a dog. J. Small Anim. Pract. 1998, 39, 595-597. [CrossRef]

197. Sævik, B.K.; Jörundsson, E.; Stachurska-Hagen, T.; Tysnes, K.; Brun-Hansen, H.; Wikström, H.C.; Robertson, L.J. Dirofilaria repens infection in a dog imported to Norway. Acta Vet. Scand. 2014, 56, 6. [CrossRef]

198. Norwegian Veterinary Institute. Infectious Diseases in Dogs Imported to Norway. Available online: https://www.vetinst.no/en/ surveillance-programmes/infectious-diseases-in-dogs-imported-to-norway (accessed on 16 July 2021).

199. Swedisch Board of Agriculture. Årsrapport Över Anmälningspliktiga Djursjukdomar 2019: Annual Statistics on Notifiable Animal Diseases under the Regulations of the Swedish Board of Agriculture (SJVFS 2012: 24) on Notifiable Animal Diseases and Infectious Agents. 2019. Available online: http://djur.jordbruksverket.se/download/18.3a2a8b84171950f8cca80788/15874676322 23/\%C3\%85rsstatistik\%202019.pdf (accessed on 27 September 2021).

200. Swedisch Board of Agriculture. Årsrapport Över Anmälningspliktiga Djursjukdomar 2018: Annual Statistics on Notifiable Animal Diseases under the Regulations of the Swedish Board of Agriculture (SJVFS 2012: 24) on Notifiable Animal Diseases and Infectious Agents. 2018. Available online: http://djur.jordbruksverket.se/download/18.3a2a8b84171950f8cca80788/15874676322 23/\%C3\%85rsstatistik\%202018.pdf (accessed on 27 September 2021).

201. Penagos-Tabares, F.; Groß, K.M.; Hirzmann, J.; Hoos, C.; Lange, M.K.; Taubert, A.; Hermosilla, C. Occurrence of canine and feline lungworms in Arion vulgaris in a park of Vienna: First report of autochthonous Angiostrongylus vasorum, Aelurostrongylus abstrusus and Troglostrongylus brevior in Austria. Parasitol. Res. 2020, 119, 327-331. [CrossRef]

202. Maier, K.; Löwenstein, M.; Duscher, G.; Leschnik, M.; Joachim, A. Angiostrongylus Vasorum, der "französische Herzwurm": Auch ein Problem in Österreich? Wiener Tierarztliche Monatsschrift 2010, 97, 171.

203. Reifinger, M.; Greszl, J. Pulmonale Angiostrongylose mit systemischer Ausbreitung und zentralnervaler Manifestation bei einem Hund. J. Vet. Med. Ser. B 1994, 41, 391-398. [CrossRef]

204. Globokar, M.; Pantchev, N.; Hinney, B.; Leschnik, M.; Peschke, R.; Schaper, R.; Schnyder, M. Serological and faecal detection of Angiostrongylus vasorum in dogs from Austria. Vet. Parasitol. Reg. Stud. Rep. 2021, 26, 10064.

205. Hajnalová, M.; Svobodová, V.; Schnyder, M.; Schaper, R.; Svoboda, M. Faecal detection of the lungworms Crenosoma vulpis and Angiostrongylus vasorum and serological detection of A. vasorum in dogs from the Czech Republic. Acta Veterinaria Brno 2017, 86, 393-398. [CrossRef]

206. Schiefer, B.; Etreby, M.E. Zur Frage der sogenannten Riesenzellpneumonie und Riesenzellbronchitis bei Tieren. Pathol. Vet. 1965, 2, 20-36. [CrossRef]

207. Pallaske, G. Zur Angiostrongylose des Hundes. Deutsche Tierarztliche Wochenschrift 1967, 74, 166-171.

208. Staebler, S.; Ochs, H.; Steffen, F.; Naegeli, F.; Borel, N.; Sieber-Ruckstuhl, N.; Deplazes, P. Autochthone Infektionen mit Angiostrongylus vasorum bei Hunden in der Schweiz und Deutschland. Schweizer Archiv für Tierheilkunde 2005, 147, 121-127. [CrossRef]

209. Denk, D.; Matiasek, K.; Just, F.T.; Hermanns, W.; Baiker, K.; Herbach, N.; Steinberg, T.; Fischer, A. Disseminated angiostrongylosis with fatal cerebral haemorrhages in two dogs in Germany: A clinical case study. Vet. Parasitol. 2009, 160, 100-108. [CrossRef]

210. Pötz, C.; Peters, M. Der klinische Fall: Disseminierte Angiostrongylus-vasorum-Infektion bei einem aus Portugal importierten Junghund. Tierarztl. Prax. Ausg. K Kleintiere. Heimtiere. 2006, 34, 356-360. [CrossRef]

211. Barutzki, D.; Schaper, R. Endoparasites in dogs and cats in Germany 1999-2002. Parasitol. Res. 2003, 90 (Suppl. 3), S148-S150. [CrossRef] 
212. Barutzki, D.; Dyachenko, V.; Schaper, R. Lungworms in Germany 2002-2016: Is there an Increase in Occurrence and Geographical Spread? Parasitol. Res. 2017, 116, 11-30. [CrossRef]

213. Barutzki, D.; Schaper, R. Results of parasitological examinations of faecal samples from cats and dogs in Germany between 2003 and 2010. Parasitol. Res. 2011, 109 (Suppl. 1), S45-S60. [CrossRef]

214. Schnyder, M.; Schaper, R.; Bilbrough, G.; Morgan, E.R.; Deplazes, P. Seroepidemiological survey for canine angiostrongylosis in dogs from Germany and the UK using combined detection of Angiostrongylus vasorum antigen and specific antibodies. Parasitology 2013, 140, 1442-1450. [CrossRef]

215. Rehbein, S.; Kaulfuß, K.-H.; Visser, M.; Sommer, M.F.; Grimm, F.; Silaghi, C. Parasites of sheep herding dogs in central Germany. Berliner und Munchener Tierarztliche Wochenschrift 2016, 129, 56-64.

216. Barutzki, D.; Schaper, R. Natural infections of Angiostrongylus vasorum and Crenosoma vulpis in dogs in Germany (2007-2009). Parasitol. Res. 2009, 105 (Suppl. 1), S39-S48. [CrossRef]

217. Maksimov, P.; Hermosilla, C.; Taubert, A.; Staubach, C.; Sauter-Louis, C.; Conraths, F.J.; Vrhovec, M.G.; Pantchev, N. GISsupported epidemiological analysis on canine Angiostrongylus vasorum and Crenosoma vulpis infections in Germany. Parasites Vectors 2017, 10, 108. [CrossRef]

218. Schulz, B.S.; Seybold, N.; Sauter-Louis, C.; Hartmann, K. Prevalence of Angiostrongylus vasorum and Crenosomo vulpis in dogs in Bavaria. Berliner und Munchener Tierarztliche Wochenschrift 2013, 126, 62-68.

219. Taubert, A.; Pantchev, N.; Vrhovec, M.G.; Bauer, C.; Hermosilla, C. Lungworm infections (Angiostrongylus vasorum, Crenosoma vulpis, Aelurostrongylus abstrusus) in dogs and cats in Germany and Denmark in 2003-2007. Vet. Parasitol. 2009, 159, 175-180. [CrossRef]

220. Schug, K.; Krämer, F.; Schaper, R.; Hirzmann, J.; Failing, K.; Hermosilla, C.; Taubert, A. Prevalence survey on lungworm (Angiostrongylus vasorum, Crenosoma vulpis, Eucoleus aerophilus) infections of wild red foxes (Vulpes vulpes) in central Germany. Parasites Vectors 2018, 11, 85. [CrossRef] [PubMed]

221. Lange, M.K.; Penagos-Tabares, F.; Hirzmann, J.; Failing, K.; Schaper, R.; van Bourgonie, Y.R.; Backeljau, T.; Hermosilla, C.; Taubert, A. Prevalence of Angiostrongylus vasorum, Aelurostrongylus abstrusus and Crenosoma vulpis larvae in native slug populations in Germany. Vet. Parasitol. 2018, 254, 120-130. [CrossRef]

222. Kotlán, S. Helminthologie: Die Helminthosen der Haus-und Nutztiere unter Berücksichtigung der Helminthosen des Menschen; Akadémiai Kiadó: Budapest, Hungary, 1960.

223. Sólymos, P.; Fehér, Z. Conservation prioritization based on distribution of land snails in Hungary. Conserv. Biol. 2005, 19, 1084-1094. [CrossRef]

224. Majoros, G.; Fukár, O.; Farkas, R. Autochtonous infection of dogs and slugs with Angiostrongylus vasorum in Hungary. Vet. Parasitol. 2010, 174, 351-354. [CrossRef] [PubMed]

225. Schnyder, M.; Schaper, R.; Lukács, Z.; Hornok, S.; Farkas, R. Combined Serological Detection of Circulating Angiostrongylus vasorum Antigen and Parasite-specific Antibodies in Dogs from Hungary. Parasitol. Res. 2015, 114, 145-154. [CrossRef]

226. Demiaszkiewicz, A.W.; Pyziel, A.M.; Kuligowska, I.; Lachowicz, J.; Demiaszkiewicz, A.W.; Pyziel, A.M. The first report of Angiostrongylus vasorum (Nematoda; Metastrongyloidea) in Poland, in red foxes (Vulpes vulpes). Acta Parasitol. 2014, 59, 758-762. [CrossRef] [PubMed]

227. Szczepaniak, K.; Tomczuk, K.; Buczek, K.; Komsta, R.; Łojszczyk-Szczepaniak, A.; Staniec, M.; Winiarczyk, S. Pierwszy rozpoznany bezpośrednio, kliniczny przypadek angiostrongylozy u psa w Polsce. Medycyna Weterynaryjna 2014, 70, 242.

228. Schnyder, M.; Schaper, R.; Pantchev, N.; Kowalska, D.; Szwedko, A.; Deplazes, P. Serological detection of circulating Angiostrongylus vasorum antigen-and parasite-specific antibodies in dogs from Poland. Parasitol. Res. 2013, 112 (Suppl. 1), $109-117$. [CrossRef]

229. Szczesna, J.; Popiolek, M.; Smietana, W. A study on the helminthfauna of wolves (Canis lupus L.) in the Bieszczady Mountains (south Poland)-preliminary results. Wiadomości Parazytologiczne 2007, 53 (Suppl. 1), 36.

230. Hurníková, Z.; Miterpáková, M.; Mandelík, R. First autochthonous case of canine Angiostrongylus vasorum in Slovakia. Parasitol. Res. 2013, 112, 3505-3508. [CrossRef]

231. Miterpáková, M.; Hurníková, Z.; Zalewski, A.P. The first clinically manifested case of angiostrongylosis in a dog in Slovakia. Acta Parasitol. 2014, 59, 661-665. [CrossRef]

232. Miterpáková, M.; Schnyder, M.; Schaper, R.; Hurníková, Z.; Čabanová, V. Serological survey for canine angiostrongylosis in Slovakia. Helminthologia 2015, 52, 205-210. [CrossRef]

233. Čabanová, V.; Hurníková, Z.; Miterpáková, M.; Dirbakova, K.; Bendova, A.; Kocak, P. Lungworm infections in dogs from Central Europe. Veterinární medicína 2018, 63, 367-372. [CrossRef]

234. Hurníková, Z.; Čabanová, V.; Karpjak, P.; Kasenčák, M.; Miterpáková, M. Rare case of Angiostrongylus vasorum intraocular infestation in an asymptomatic dog. Helminthologia 2019, 56, 319. [CrossRef]

235. Čabanová, V.; Guimaraes, N.; Hurníková, Z.; Chovancová, G.; Urban, P.; Miterpáková, M. Endoparasites of the grey wolf (Canis lupus) in protected areas of Slovakia. Ann. Parasitol. 2017, 63, 283-289. [CrossRef] [PubMed]

236. Wolff, K.; Eckert, J.; Leemann, W. Beitrag zur Angiostrongylose des Hundes. Dtsch Vet-Med Ges Zürich 1969, 10, 9-11.

237. Gottstein, B. Lungenwurm Angiostrongylus vasorum bei einem Fuchs in der Schweiz. BVET-Mag. 2001, 1, 22. 
238. Schnyder, M.; Jefferies, R.; Schucan, A.; Morgan, E.R.; Deplazes, P. Comparison of coprological, immunological and molecular methods for the detection of dogs infected with Angiostrongylus vasorum before and after anthelmintic treatment. Parasitology 2015, 142, 1270-1277. [CrossRef] [PubMed]

239. Lurati, L.; Deplazes, P.; Hegglin, D.; Schnyder, M. Seroepidemiological survey and spatial analysis of the occurrence of Angiostrongylus vasorum in Swiss dogs in relation to biogeographic aspects. Vet. Parasitol. 2015, 212, 219-226. [CrossRef]

240. Koller, B.; Hegglin, D.; Schnyder, M. A grid-cell based fecal sampling scheme reveals: Land-use and altitude affect prevalence rates of Angiostrongylus vasorum and other parasites of red foxes (Vulpes vulpes). Parasitol. Res. 2019, 118, 2235-2245. [CrossRef]

241. Deplazes, P.; Hegglin, D.; Gloor, S.; Romig, T. Wilderness in the city: The urbanization of Echinococcus multilocularis. Trends Parasitol. 2004, 20, 77-84. [CrossRef]

242. Finnerup, E. Angiostrongylus vasorum hos hund. Dansk Veterinærtidsskrift 1983, 66, 338-340.

243. Koch, J.; Bolt, G. Angiostrongylus vasorum hos hund (Canine angiostrongylosis). Dansk Veterinærtidsskrift 1990, $73,1239-1243$.

244. Rosenlund, P.; Boserup, F.; Monrad, J. Angiostrongylus vasorum I forreste ojenkammer hos hund. Dansk-Vet Tidsskr 1991, 74, 451-453.

245. Bolt, G.; Monrad, J.; Henriksen, P.; Dietz, H.H.; Koch, J.; Bindseil, E.; Jensen, A.L. The fox (Vulpes vulpes) as a reservoir for canine angiostrongylosis in Denmark. Field survey and experimental infections. Acta Vet. Scand. 1992, 33, 357-362. [CrossRef]

246. Guildal, J.A.; Clausen, B. Endoparasites from one hundred Danish red foxes (Vulpes vulpes (L.)). Nor. J. Zool. 1973, $21,329-330$.

247. Saeed, I.; Maddox-Hyttel, C.; Monrad, J.; Kapel, C.M.O. Helminths of red foxes (Vulpes vulpes) in Denmark. Vet. Parasitol. 2006, 139, 168-179. [CrossRef]

248. Jacobsen, D.K.L. Prævalensundersøgelse af Crenosoma vulpis og Angiostrongylus Vasorum Hos ræv (Vulpes vulpes) og hund (Canis familiaris) i et område i Midtjylland-DK. Available online: https:/ /www.ddd.dk/media/2130/2007-08-keld-loekkegaardjacobsen.pdf (accessed on 20 July 2021).

249. Al-Sabi, M.N.S.; Halasa, T.; Kapel, C.M.O. Infections with cardiopulmonary and intestinal helminths and sarcoptic mange in red foxes from two different localities in Denmark. Acta Parasitol. 2014, 59, 98-107. [CrossRef]

250. Söderblom, A.; Saari, S.; Järvinen, A.-K. Angiostrongylus vasorum-tartunta tuontikoiralla: Ensimmäinen varmistettu tapaus Suomessa. Suomen eläinlä̈̈kärilehti 2008, 114, 199-208.

251. Freeman, R.S. Helminth parasites of the red fox in Finland 1963-1964. In Proceedings of the First International Congress of Parasitology, Roma, Italy, 21-26 September 1964; Corradetti, A., Ed.; Elsevier: Amsterdam, The Netherlands; Elsevier Science: Burlington, MA, USA, 1966; p. 482, ISBN 978-1-4832-2913-3.

252. Isomursu, M.; Salin, N.; Oksanen, A. Rare canine parasites survive in the wild fox population. Acta Vet. Scand. 2010, 52, 173. [CrossRef]

253. Skírnisson, K.; Pálsdóttir, G.R.; Eydal, M. Parasites of dogs and cats imported to Iceland during $1989-2017$ with remarks on parasites occurring in the native populations. IAS 2018, 31, 49-63. [CrossRef]

254. Davidson, R.K.; Gjerde, B.; Vikøren, T.; Lillehaug, A.; Handeland, K. Prevalence of Trichinella larvae and extra-intestinal nematodes in Norwegian red foxes (Vulpes vulpes). Vet. Parasitol. 2006, 136, 307-316. [CrossRef]

255. Norwegian Veterinary Institute. Angiostrongylus Vasorum in Red Foxes. Available online: https://www.vetinst.no/en/ surveillance-programmes/angiostrongylus-vasorum-in-red-foxes (accessed on 16 July 2021).

256. Norwegian Food Safety Authority. The Surveillance Programme for Angiostrongylus Vasorum in Red Foxes (Vulpes vulpes) in Norway 2019: Annual Report; Norwegian Veterinary Institute: Ås, Norway, 2020.

257. Åblad, B.; Christensson, D.; Osterman-Lind, E.; Ågren, E.; Mörner, T. Angiostrongylus vasorum etablerad i Sverige. Svensk Veterinartidning 2003, 12, 11-15.

258. Al-Sabi, M.N.S. Gastrointestinal helminths of gray wolves (Canis lupus lupus) from Sweden. Parasitol. Res. 2018, 117, 1891-1898. [CrossRef]

259. Silaghi, C.; Beck, R.; Capelli, G.; Montarsi, F.; Mathis, A. Development of Dirofilaria immitis and Dirofilaria repens in Aedes japonicus and Aedes geniculatus. Parasites Vectors 2017, 10, 94. [CrossRef]

260. Ionică, A.M.; Zittra, C.; Wimmer, V.; Leitner, N.; Votýpka, J.; Modrý, D.; Mihalca, A.D.; Fuehrer, H.-P. Mosquitoes in the Danube Delta: Searching for vectors of filarioid helminths and avian malaria. Parasites Vectors 2017, 10, 324. [CrossRef]

261. Cancrini, G.; Magi, M.; Gabrielli, S.; Arispici, M.; Tolari, F.; Dell'Omodarme, M.; Prati, M.C. Natural vectors of dirofilariasis in rural and urban areas of the Tuscan region, central Italy. J. Med. Entomol. 2006, 43, 574-579. [CrossRef]

262. Cancrini, G.; Gabrielli, S. Vectors of Dirofilaria nematodes: Biology, behaviour and host/parasite relationships. In Dirofilaria Immitis and D. Repens in Dog and Cat and Human Infections; Rolando Editore: Naples, Italy, 2007; pp. 48-58.

263. Pollono, F.; Cancrini, G.; Rossi, L. Survey on Culicidae attracted to bait dog in piedmont. Parassitologia 1998, 40, 439-445.

264. Ahid, S.M.; Vasconcelos, P.S.; Lourenço-de-Oliviera, R. Vector competence of Culex quinquefasciatus say from different regions of Brazil to Dirofilaria immitis. Mem. Inst. Oswaldo Cruz 2000, 95, 769-775. [CrossRef]

265. Anderson, J.F.; Main, A.J.; Ferrandino, F.J.; Andreadis, T.G. Nocturnal activity of mosquitoes (Diptera: Culicidae) in a West Nile virus focus in Connecticut. J. Med. Entomol. 2007, 44, 1102-1108. [CrossRef] [PubMed]

266. Medlock, J.M.; Hansford, K.M.; Schaffner, F.; Versteirt, V.; Hendrickx, G.; Zeller, H.; van Bortel, W. A review of the invasive mosquitoes in Europe: Ecology, public health risks, and control options. Vector Borne Zoonotic Dis. 2012, 12, 435-447. [CrossRef] [PubMed] 
267. Scholte, E.-J.; Schaffner, F. Waiting for the tiger: Establishment and spread of the Aedes albopictus mosquito in Europe. Emerg. Pests Vector-Borne Dis. Eur. 2007, 1, 241.

268. Becker, N.; Petric, D.; Zgomba, M.; Boase, C.; Madon, M.; Dahl, C.; Kaiser, A. Mosquitoes and Their Control; Springer Science \& Business Media: Berlin/Heidelberg, Germany, 2010; ISBN 354092874X.

269. Giangaspero, A.; Marangi, M.; Latrofa, M.S.; Martinelli, D.; Traversa, D.; Otranto, D.; Genchi, C. Evidences of increasing risk of dirofilarioses in southern Italy. Parasitol. Res. 2013, 112, 1357-1361. [CrossRef]

270. Pietrobelli, M. Importance of Aedes albopictus in veterinary medicine. Parassitologia 2008, 50, 113-115. [PubMed]

271. Brown, H.E.; Harrington, L.C.; Kaufman, P.E.; McKay, T.; Bowman, D.D.; Nelson, C.T.; Wang, D.; Lund, R. Key factors influencing canine heartworm, Dirofilaria immitis, in the United States. Parasites Vectors 2012, 5, 245. [CrossRef] [PubMed]

272. Morgan, E.R.; Tomlinson, A.; Hunter, S.; Nichols, T.; Roberts, E.; Fox, M.T.; Taylor, M.A. Angiostrongylus vasorum and Eucoleus aerophilus in foxes (Vulpes vulpes) in Great Britain. Vet. Parasitol. 2008, 154, 48-57. [CrossRef] [PubMed]

273. Kirk, L.; Limon, G.; Guitian, F.J.; Hermosilla, C.; Fox, M.T. Angiostrongylus vasorum in Great Britain: A nationwide postal questionnaire survey of veterinary practices. Vet. Rec. 2014, 175, 118. [CrossRef] [PubMed]

274. Morgan, E.R. Canine pulmonary angiostrongylosis: Can a worm change its spots? Vet. Rec. 2014, 175, 116-117. [CrossRef]

275. Blancou, J. Ecology and epidemiology of fox rabies. Rev. Infect. Dis. 1988, 10 (Suppl. 4), S606-S609. [CrossRef]

276. Woolsey, I.D.; Webster, P.; Thamsborg, S.; Schnyder, M.; Monrad, J.; Kapel, C.M.O. Repeated inoculations with the lung and heartworm nematode Angiostrongylus vasorum result in increasing larval excretion and worm burden in the red fox (Vulpes vulpes). Int. J. Parasitol. Parasites Wildl. 2017, 6, 139-145. [CrossRef]

277. Schnyder, M. Slugs and Angiostrongylus vasorum-how much do we know? Vet. Rec. 2015, 177, 44-45. [CrossRef]

278. Ferdushy, T.; Kapel, C.M.O.; Webster, P.; Al-Sabi, M.N.S.; Grønvold, J.R. The effect of temperature and host age on the infectivity and development of Angiostrongylus vasorum in the slug Arion lusitanicus. Parasitol. Res. 2010, 107, 147-151. [CrossRef]

279. Di Cesare, A.; Crisi, P.E.; Di Giulio, E.; Veronesi, F.; Di Regalbono, A.F.; Talone, T.; Traversa, D. Larval development of the feline lungworm Aelurostrongylus abstrusus in Helix aspersa. Parasitol. Res. 2013, 112, 3101-3108. [CrossRef]

280. Morelli, S.; Traversa, D.; Colombo, M.; Raue, K.; Strube, C.; Pollmeier, M.; Di Cesare, A. The effect of the hibernation on the larval development of Troglostrongylus brevior in the land snail Cornu aspersum. Vet. Parasitol. 2020, 282, 109123. [CrossRef] [PubMed]

281. Morelli, S.; Colombo, M.; Diakou, A.; Traversa, D.; Grillini, M.; Di Regalbono, A.F.; Di Cesare, A. The Influence of Temperature on the Larval Development of Aelurostrongylus abstrusus in the Land Snail Cornu aspersum. Pathogens 2021, 10, 960. [CrossRef] [PubMed]

282. Olivieri, E.; Zanzani, S.A.; Gazzonis, A.L.; Giudice, C.; Brambilla, P.; Alberti, I.; Romussi, S.; Lombardo, R.; Mortellaro, C.M.; Banco, B.; et al. Angiostrongylus vasorum infection in dogs from a cardiopulmonary dirofilariosis endemic area of Northwestern Italy: A case study and a retrospective data analysis. BMC Vet. Res. 2017, 13, 165. [CrossRef]

283. Traversa, D.; Morelli, S.; Cassini, R.; Crisi, P.E.; Russi, I.; Grillotti, E.; Manzocchi, S.; Simonato, G.; Beraldo, P.; Viglietti, A.; et al. Occurrence of canine and feline extra-intestinal nematodes in key endemic regions of Italy. Acta Trop. 2019, 193, 227-235. [CrossRef]

284. Drake, J.; Parrish, R. Dog importation and changes in canine intestinal nematode prevalence in Colorado, USA, $2013-2017$. Parasites Vectors 2020, 13, 404. [CrossRef]

285. Perry, A.W.; Hertling, R.; Kennedy, M.J. Angiostrongylosis with disseminated larval infection associated with signs of ocular and nervous disease in an imported dog. Can. Vet. J. 1991, 32, 430-431.

286. Tebb, A.I.; Johnson, V.S.; Irwin, P.J. Angiostrongylus vasorum (French heartworm) in a dog imported into Australia. Aust. Vet. J. 2007, 85, 23-28. [CrossRef] [PubMed]

287. Williams, J.F.; Lindemann, B.; Padgett, G.A.; Smith, O.L. Angiostrongylosis in a greyhound. J. Am. Vet. Med. Assoc. 1985, 186, 1101-1103. [PubMed] 